NBER WORKING PAPER SERIES

TRADE REFORMS AND CURRENT ACCOUNT IMBALANCES

\author{
Jiandong Ju \\ Kang Shi \\ Shang-Jin Wei \\ Working Paper 18653 \\ http://www.nber.org/papers/w18653 \\ NATIONAL BUREAU OF ECONOMIC RESEARCH \\ 1050 Massachusetts Avenue \\ Cambridge, MA 02138 \\ December 2012, Revised February 2021
}

We thank Jonathan Eaton, Takatoshi Ito, Maurice Obstfeld, Andrew Rose, Stephanie SchmittGrohe, Nelson Mark, Vincenzo Quadrini, Michael Song, Martin Uribe, and seminar/conference participants at NBER International Trade and Investment Program meeting, NBER East Asia Conference, San Francisco Federal Reserve Paci c Basin Research Conference, China Economics Summer Institute, Columbia University, IMF, and the World Bank for helpful comments. We thank Hanyi Tao, Junjie Tang, and Xinding Yu for very able research assistance and Joy Glazener and Nikhil Patel for editorial assistance. All errors are our responsibilities. The views expressed herein are those of the authors and do not necessarily reflect the views of the National Bureau of Economic Research.

NBER working papers are circulated for discussion and comment purposes. They have not been peer-reviewed or been subject to the review by the NBER Board of Directors that accompanies official NBER publications.

(C) 2012 by Jiandong Ju, Kang Shi, and Shang-Jin Wei. All rights reserved. Short sections of text, not to exceed two paragraphs, may be quoted without explicit permission provided that full credit, including $\odot$ notice, is given to the source. 
Trade Reforms and Current Account Imbalances

Jiandong Ju, Kang Shi, and Shang-Jin Wei

NBER Working Paper No. 18653

December 2012, Revised February 2021

JEL No. F2,F3

\section{$\underline{\text { ABSTRACT }}$}

This paper studies the effects of trade liberalization on capital flows in a dynamic HeckscherOhlin model, and makes four contributions. First, we identify an interest rate over-determination problem in such a model, and solve it with an endogenous discount factor. Second, we show that a trade liberalization in a developing country generally leads to a greater current account surplus, which is the exact opposite of a common but partial equilibrium intuition. Third, factor market reforms reinforce the effect of the trade liberalization on capital outflows. Finally, our calibrations suggest that China's accession to the WTO is likely an important factor driving the rise of its current account surplus.

Jiandong $\mathrm{Ju}$

Tsinghua PBC

Beijing 100083, China

jujd@pbcsf.tsinghua.edu.cn

Kang Shi

Department of Economics

Chinese University of Hong Kong

Shatin, New Territories

Hong Kong

kangshi@cuhk.edu.hk

\author{
Shang-Jin Wei \\ Graduate School of Business \\ Columbia University \\ Uris Hall 619 \\ 3022 Broadway \\ New York, NY 10027-6902 \\ and NBER \\ shangjin.wei@columbia.edu
}




\title{
Trade Reforms and Current Account Imbalances
}

\author{
Jiandong Ju, Kang Shi, Shang-Jin Wei*
}

January 2021

\begin{abstract}
This paper studies the effects of trade liberalization on capital flows in a dynamic Heckscher-Ohlin model, and makes four contributions. First, we identify an interest rate over-determination problem in such a model, and solve it with an endogenous discount factor. Second, we show that a trade liberalization in a developing country generally leads to a greater current account surplus, which is the exact opposite of a common but partial equilibrium intuition. Third, factor market reforms reinforce the effect of the trade liberalization on capital outflows. Finally, our calibrations suggest that China's accession to the WTO is likely an important factor driving the rise of its current account surplus.
\end{abstract}

\section{Introduction}

How does a reduction in trade costs such as a unilateral tariff cut by the importing country affects its current account? If the lower costs of importing translate into more imports, one is tempted to conclude that the importing country's current account should deteriorate (i.e. generating either a bigger deficit or a smaller surplus). This is a partial equilibrium

\footnotetext{
*Ju: PBC school of Finance, Tsinghua University, (E-mail) jujd@pbcsf.tinghua.edu.cn; Shi: Chinese University of Hong Kong, (E-mail) kangshi@cuhk.edu.hk; and Wei: Columbia Business School, CEPR, CIER, and NBER, (E-mail) shangjin.wei@columbia.edu. We thank Jonathan Eaton, Takatoshi Ito, Maurice Obstfeld, Andrew Rose, Stephanie Schmitt-Grohe, Nelson Mark, Vincenzo Quadrini, Michael Song, Martin Uribe, and seminar/conference participants at NBER International Trade and Investment Program meeting, NBER East Asia Conference, San Francisco Federal Reserve Pacific Basin Research Conference, China Economics Summer Institute, Columbia University, IMF, and the World Bank for helpful comments. We thank Hanyi Tao, Junjie Tang, and Xinding Yu for very able research assistance and Joy Glazener and Nikhil Patel for editorial assistance. All errors are our responsibilities.
} 
intuition. In this paper, we argue that the general equilibrium effect can often have an opposite sign from a partial equilibrium effect, especially for developing countries.

In media and policy discussions, it is often assumed that a country's restrictions on imports contribute to its current account surplus. In 1989, a well-known article titled "Containing Japan" by James Fallows, in the Atlantic magazine, blamed import restrictions by Japan for its large trade surplus. In more recent years, media stories often blame import restrictions by China as a contributing factor to the latter's trade and current account surplus. Indeed, it is commonly assumed that, when a country liberalizes trade (i.e., reducing trade barriers on imports), its trade surplus would shrink. One key message of the current paper is that such an assertion is not correct. Instead, we will show that, for a typical developing country, reducing import barriers can be expected to improve (rather than worsen) its current account.

To accomplish this, we propose a dynamic Heckscher-Ohlin framework, with a necessary modification of the standard setup to overcome the challenge of an interest rate overdetermination - to be explained below, to study permanent shocks such as a permanent tariff cut $^{1}$. Our calibration suggests that China's accession to the World Trade Organization in 2001, with the attendant reductions in its import barriers, is a significant contributor to the big surge in its current account surplus in the years following the reforms.

National trade barriers tend to be placed on products in which the country in question does not have a comparative advantage. For a typical developing (labor abundant) country, trade barriers are likely to be disproportionately on capital intensive goods. A reduction in the import barriers on the capital-intensive good reduces the domestic return to capital, all else equal. This is the intuition one obtains from the Stolper-Samuelson theorem in the static trade theory. If the pre-liberation return to capital was equal to the world interest rate

\footnotetext{
${ }^{1}$ The Heckscher-Ohlin framework has been found empirically relevant by several papers recently. Hanson (2012) argues that the rise of North-South trade in recent decades has rekindled an interest in the role of comparative advantage in global production. He also provides evidence that cross-country differences in technology and resources are potent motivations for international trade. Romalis (2004) finds supportive evidence for the factor endowment theory. First, countries tend to capture a larger share of world production and trade in commodities that require more intensive use of their abundant factors. Second, countries that rapidly accumulate a factor see their production and export structures systematically shift towards those industries that are intensive users of that factor. While these papers use a static HO framework, we develop a dynamic HO model in this paper. Reyes-Heroles, Traiberman, and Van Leemput (2020) provide additional evidences on the relevance of the HO type of comparative advantage for understanding trade patterns across developed and emerging economies.
} 
(after adjusting for risk premium and transaction costs), the import liberalization upsets the equilibrium, by reducing the returns to the relatively scarce factor (i.e., capital) and thus rendering the domestic interest rate to be lower than its international counterpart. To restore the equilibrium, the country must export enough capital, i.e., running a current account surplus.

Trade liberalizations would generally induce an opposite current account response in a rich (or capital abundant) country. Reductions in trade barriers (of the labor-intensive good) in such a country should raise the return to capital by the logic of the StolperSamuelson theorem. As a result, the country would attract capital inflow, i.e., creating a current account deficit.

The paper aims to make four contributions. The first is to build a dynamic model with Heckscher-Ohlin (HO) features and use it to show that reductions in import tariffs generally lead to a capital outflow for a labor abundant economy. Specifically, we prove that the Stolper-Samuelson theorem that holds in a static HO model also holds in our dynamic setup, and this produces a general-equilibrium that is the opposite of the partial equilibrium effect. Jin (2012), using an overlapping generations (OLG) model with sectorspecific capital, also shows that trade reforms can produce a current account surplus in a labor abundant country. Her mechanism is not Stolper-Samuelson. Through calibration, she shows that a composition effect can dominate the standard convergence force. However, what works in an OLG model need not carry over to an infinite-horizon model. For example, Obstfeld and Rogoff (1996) show that overlapping generation models and infinite-horizon models give different answers to some key questions in open-economy macroeconomics. In particular, a persistent and positive productivity shock generates a current account deficit in an infinite-horizon model due to consumption smoothing, but a current account surplus in an OLG model due to life-cycle saving motivation. Romer (2011) suggests that an infinitehorizon model is a more natural benchmark for the dynamic case than an OLG setup since the former can avoid market imperfections and other issues raised by heterogeneous households in an OLG model. According to Minford and Peel (2002), while an OLG model is helpful to think about long-lived shocks to demographics and productivity, an infinitehorizon model is more useful to think about dynamics over short or medium terms. This suggests strong value-added in investigating whether this result holds in an infinite-horizon 
model. This paper performs this useful task.

The second contribution is methodological in nature. It clarifies and solves an interest rate over-determination problem in a dynamic HO model. In the standard static HO model, if the economy is within the diversification cone, the interest rate is determined by the zeroprofit conditions from the supply side. That is, the interest rate, together with the wage, is completely determined by goods prices and tariff rates. Preference parameters such as the time discount factor play no role. However, in a standard infinite-horizon one-sector model, the interest rate in the steady state is determined by the time discount factor from the demand side. When the two models are merged into a dynamic HO setup, the two interest rates from the two approaches would not be the same in general except by coincidence. Even assuming that the two are the same initially, any permanent shock such as trade liberalization would cause the two to diverge again. A version of the problem appears in a two-country dynamic HO model in Stiglitz (1970) when he shows that, unless the two countries have identical discount factors, one country must specialize completely. As a complete specialization does not appear to describe the real world well ${ }^{2}$, and in any case, it is hard to discuss structural changes in a model with complete specialization, so it is desirable to have an intertemporal model with a $\mathrm{HO}$ structure that overcomes the problem of interest rate over-determination.

Our solution is to introduce an endogenous discount factor. In that case, the interest rate is determined by the zero-profit conditions as in the static HO model. With an endogenous discount factor, the total consumption in the steady state would simply adjust to conform with the interest rate, avoiding over-determination or inconsistency. With such a modification, the effect of trade reforms on current accounts can be analyzed. An endogenous discount rate is a discount rate that varies over time, for example, as a function of the economy-wide consumption per capita and income per capita. An endogenous discount factor is not just a technical convenience, but, at a philosophical level, can also be regarded as capturing an important part of human nature.

There is a natural connection between our first and second contributions. The Stolper-

\footnotetext{
${ }^{2}$ Countries can specialize partially. For example, a developed country can specialize in producing airplanes and rockets, and a developing country can specialize in producing rice and textile, However, as long as both countries produce steel and furniture, the zero-profit conditions determine interest rates. In other words, the interest rate over-determination can arise with partial specialization.
} 
Samuelson theorem has not been proven in a dynamic HO model in the literature probably because the interest rate over-determination problem has not been tackled in such a setup. The new Stolper-Samuelson theorem provides a mechanism for the current account to react in a seemingly counter-intuitive way following a permanent shock to the trade policy.

The third contribution is to study the interaction between factor market reforms and trade reforms and their effects on the current account. Many trade reforms such as an accession to the WTO often involve domestic factor reforms as well. We investigate whether and how domestic capital market reforms reinforce or weaken the effect of trade reforms on the current account. This has important practical implications. For example, in the case of China's accession to the WTO, the country has agreed to a set of policy changes pertaining to the functioning of the domestic financial system, including increased openness to foreign banks, in addition to reducing import barriers. We show that, with financial market reforms, a given amount of tariff cut generates a bigger current account surplus. This theoretical result helps us to understand why the Chinese trade reform in the early 2000s produces a bigger current account response than the reforms in the 1980s and 1990s.

As a fourth contribution, we provide a new interpretation about the observed rise and fall of China's current account surplus since 2001. Using the lens of our framework, China's accession to the World Trade Organization at the end of 2001 (with massive cuts in the country's tariffs and, importantly, non-tariff import barriers) was a watershed event for both China and the rest of the world. Our model predicts that China would initially generate a current account surplus following the WTO accession. Because many trade reform measures were implemented in a phased manner, the current account surplus would rise for a number of years. Interestingly, the same model also predicts that the current account surplus would eventually shrink. This is because the economy will eventually converge to a new steady state in which the net foreign asset remains a constant, and the current account balance will also converge to zero after the trade reform. In other words, an inverse- $\mathrm{V}$-shape of current account dynamics in response to tariff cuts emerges naturally in our model. (In all dynamic models, the effect of a shock on the current account would eventually disappear, but they do not always produce a rise-and-fall pattern following tariff cuts.)

This inverse- $\mathrm{V}$-shape theoretical prediction is broadly consistent with the data. Figure 1 traces out the trajectory of China's trade-weighted average tariff rate from 1998 to 2010 . 
The average tariff rate was as high as $14 \%$ before 2001 (with tariff rates on many capitalintensive goods in excess of $50 \%$ ) but declined in phases to a more modest $5 \%$ by 2004 and stayed that low afterwards. Consistent with our theoretical model, China's current account surplus was very mild in the year before China joined the WTO, but started to rise noticeably afterward until 2007 when it began to fall. The standard explanation blames the Chinese exchange rate policy for the initial rise, and the contraction of trade volume triggered by the global financial crisis for the decline in the current account imbalance since 2008. Our model suggests another contributing factor at play - the same initial shock of China's WTO accession can simultaneously generate the initial rise in the imbalance and the subsequent fall.

In sum, our theory suggests that trade liberalizations in China may have played a significant role in both the initial rise in the current account surplus and the subsequent fall. This is the exact opposite to the commonly accepted partial equilibrium intuition that lower import barriers would lead to a reduction in the trade balance. By this perspective, instead of being driven by underlying distortions in an economy, current account imbalances can arise as an equilibrium response to welfare-improving trade reforms. Therefore, not all current account imbalances need policy corrections.

The paper is organized as follows. Section 2 provides a literature review and some suggestive patterns in the data as motivations for our model. After a basic model is presented in Section 3, the effects of trade reforms on the current account and other macroeconomic variables are derived in Section 4. The interactions between factor market flexibility and trade reforms are discussed in Section 5. Finally, concluding remarks are offered in Section 6.

\section{Background Information}

\subsection{Comparison to the Existing Literature}

We explain the contributions of this paper by comparing it to the existing literature that extends models of international trade into studies of current account. Based on Ricardian comparative advantage, Eaton et al. (2016) and Reyes-Heroles (2015) extend the static Eaton and Kortum model (2002) to a dynamic setup. The former studies the trade collapse 
during the Great Recession where trade imbalances arise from the solution to a planner's problem, while the latter considers the role of trade costs on trade imbalances. ${ }^{3}$ Unlike our paper, these models feature a single factor of production and do not consider changes in the composition of tradable sectors (with different factor intensities) as a channel of adjustment. The intuition for how a trade cost reduction affects current account imbalances is related to the classic paper by Obstfeld and Rogoff (2000) in which the trade cost acts as a tax on the intertemporal trade (capital flows).

Note that the form of trade costs is important. For example, Alessandria, Choi, and Lu (2016) study the effects of China's accession to WTO on China's current account surplus in a macroeconomic model that embeds a Melitz-style heterogeneous firm model. There is a single factor in production and therefore no adjustment in the composition of tradable sectors with different factor intensities. To generate an increase in trade imbalance, the model requires China's trading partners (not China itself) to reduce trade costs (which reduces the fixed entry costs for foreign firms to export to these markets), and also a symmetric reduction in variable trading costs (e.g., variable costs of transportation) for both Chinese and partners' exports. The calibration results are consistent with the conventional wisdom: if China's trading partners reduce import barriers more than China does, China's trade surplus goes up. However, the actual evolution of trade costs is different from this path. China's WTO accession in 2001 required China to unilaterally reduce the costs of imports from foreign partners, while its partner countries did not need to liberalize. (Except for the PNTR reform by the United States, other countries do not need to reduce their trade barriers to satisfy China's WTO membership. Even in the case of the United States, the reduction in trade barriers is smaller than the reduction in Chinese trade barriers on capital intensive goods.) This fact deviates greatly from the assumptions of the model. In ReyesHeroles (2015), whether a country runs a surplus or a deficit is not determined by changes in trade costs per se, but by the initial position of the current account. Finally, Barattieri (2014 and 2018) argues that the interplay between the US comparative advantage in the service sector and the asymmetric trade liberalization process that focused on trade in goods in the last two decades can also lead to the global imbalance.

The empirical relationship between trade reforms and current accounts has been exam-

\footnotetext{
${ }^{3}$ Reyes-Heroles (2015) calibrates the model and shows that $69 \%$ of the increase in world trade imbalances can be explained by decreases in trade costs across countries.
} 
ined by Ostry and Rose (1992) and Ju, Wu, and Zeng (2010). They find the relationship to be ambiguous. But these papers do not examine interactions between a country's factor endowment pattern and trade reforms. Our theoretical model provides an explanation for this ambiguity as it shows that the effects of trade reform on the current account depend on whether a country is relatively labor abundant and whether the pre-liberalization protection is mostly on capital intensive goods.

Our paper is related to a small but growing literature that studies international capital flows in dynamic HO models. These papers include Cunat and Maffezzoli (2004), Ju and Wei (2007), and Ju, Shi, and Wei (2014). Cunat and Maffezzoli (2004) develop a twocountry model with Hecksher-Ohlin structure to study the correlation between the terms of trade and the output. In their model, trade is balanced by assumption and hence there is no interesting current account dynamics. Ju and Wei (2007) and Ju, Shi, and Wei (2014) investigate how the domestic labor market affects the current account dynamics in a dynamic Hecksher-Ohlin framework. However, these papers do not address the interest rate over-determination problem and do not study tariff changes or other permanent shocks that can alter the interest rate.

As mentioned earlier, Jin's (2012) pioneering work has demonstrated that trade liberalization can lead to capital flows from a country with a low capital/labor ratio when the composition effect dominates the convergence effect. She constructs an overlapping generations (OLG) model that features sector-specific capital inputs. Through calibrations, she shows that a move from trade autarky to free trade can generate a current account surplus. In principle, with different parameters, the convergence effect could also dominate the composition effect, in which case the opposite result on current account can occur.

We differ from Jin's model in several ways. First, we have a dynamic Heckscher-Ohlin setup rather than an OLG setup. These models do not always give the same predictions. As an infinite horizon model is often favored as a workhorse model for current account questions, we provide such a framework. Second, an infinite horizon HO model that examines permanent shocks such as trade reforms have to confront an interest rate over-determination problem. We provide a solution to the problem. Third, following China's WTO accession, we see that the labor-intensive exports have grown faster than total exports, a rapid increase in the real wage, and a decline in the return to capital (as measured by the stock market 
returns $)^{4}$. These patterns emerge naturally out of our dynamic HO model, but much less so from the specific-factor OLG setup in Jin (2012).

This paper is also related to several papers on the cause of global current account imbalances. Caballero, Farhi, and Gourinchas (2008) and Mendoza, Quadrini, and RiosRull (2009) highlight the role of differences in financial development between current account surplus and deficit countries. Countries with relatively weak financial development (e.g., China) cannot produce enough financial assets at home to absorb all the savings. As a result, they export a part of their savings to countries with better financial development (e.g., the United States). Song, Storesletten, and Zilibotti (2011) also feature financial sector imperfections in China in generating a current account surplus. It stresses the inability of productive domestic private sector firms to borrow from the formal financial sector as key friction. These firms have to save to finance their investment. As the share of these firms grows in the economy, so does the country's current account surplus. In these papers, when China's financial market develops (including improvement in access to finance by private firms), the country's current account surplus would decline rather than increase. In contrast, our theory in this paper will suggest that factor market reforms such as improvements in the domestic financial market will reinforce the effect of trade liberalization on the current account, i.e., making the surplus even bigger than without the improvement in the financial sector.

\footnotetext{
${ }^{4}$ Assuming that the entire Chinese economy can be characterized by a one-sector Cobb-Douglas production function, Bai et al. (2006) estimate the return to capital by the ratio of aggregate output to aggregate capital stock. By this methodology, the ratio of output to capital stock does not exhibit a decline after 2011. However, besides potential noises in the capital stock estimates, using the lens of our model, this is not a conceptually valid approach. Instead, in a world with an HO structure, the return to capital is independent of the ratio of output to capital stock. One place to look for data on returns to capital is stock prices, though one needs to be mindful of potential noises in such prices especially at a high frequency. To reduce the influence of firm-level noise, we compute the market-wide returns using the Shanghai stock market composite index (https://www.macrotrends.net/2592/shanghai-composite-index-china-stockmarket-chart-data). To reduce the noise in high-frequency price fluctuations, we compute returns over five-year periods. The average return over 1996-2000 (the last five years just before China joined the WTO in December 2001) was $11.7 \%$ per year. In comparison, the average return over 2002-2006 (the first five years after China's WTO membership) was $4.2 \%$ per year. As the inflation differential between the two periods is much smaller, this suggests that the return to capital has indeed declined from the pre-WTO years to the post-WTO years. Note that we have skipped the months in 2001 as the news of a successful conclusion of the negotiation may already be incorporated in the stock prices of these months. When we include the returns in these months in the computation of the pre-WTO annualized return, we still reach the same conclusion. To summarize, the returns to capital as reflected in the stock prices are consistent with the prediction of our model.
} 


\subsection{Some Data Patterns}

Before we present a formal model, it is useful to look at more facts beyond the China example. To this end, we examine the current account experience of all countries that have experienced a major trade policy change in the last two decades. More precisely, we adopt a two-step procedure. First, we identify all episodes of large trade policy changes for all countries since 1990 (for which the relevant data are available). Second, for each country in the sample, we measure changes in the country's capital intensity and examine its relationship with changes in the country's current account.

We define a major trade reform as one that simultaneously satisfies two criteria: (a) a reduction in the country's average tariff rate (either simple tariff or trade-weighted average across products) by at least 3 percentage points cumulative over two consecutive years; and (b) an increase in the country's imports/GDP ratio by at least 3 percentage points from the year before the tariff cut to three years after the reform. The first criteria is to ensure that a chosen episode involves an actual change in the trade policy, and the second criteria is to ensure that the tariff cut is not offset by hidden increases in protectionism via non-tariff measures.

Some trade reforms may result in a decline in the country's overall capital intensity of its production, while others may produce an increase in capital intensity. Our theory will suggest that the current account consequence of a given change in the trade policy differs in these two cases. We now perform a simple check on whether, following a major trade policy change, the change in a country's current account pattern is systematically related to the change in its capital intensity.

While it is relatively straightforward to measure a change in a country's current account, how do we measure a change in its capital intensity? Our approach is to measure the capital intensity of the country's export structure before and after the trade policy change. (Ideally, we would like to measure the capital intensity of the country's entire production structure, but we do not have as good data on the sector-level production as that on sector-level exports.) We do it in two steps. First, we use the 2002 US Standard Make and Use Tables (from the US Bureau of Economic Analysis) to compute the capital intensity of each HS 6 -digit sector. Second, for a given country in the sample in any given year, we can compute the average capital intensity of its export bundle based on the shares of each HS 6-digit 
sector. Our maintained assumption is that the capital intensity of a sector is a technological feature that does not change across countries. (What we need is a weaker assumption: the ranking of sectors in terms of capital intensity, rather than the absolute values of capital intensity, is highly correlated across countries. $)^{5}$

By our filtering criteria, there are 38 episodes, involving 31 distinct countries, that qualify as major trade reforms. Unfortunately, 8 of the episodes suffer from missing data on either trade intensity (Bangladesh 2007, Bhutan, Lesotho, Pakistan, Philippines, Syria, Zimbabwe) or current account (Lebanon). Two episodes appear to be obvious outliers (Belize and Guyana) as their changes in trade composition are substantially bigger than other country-episodes. A list of the 38 trade reform episodes is provided in Table 1, together with the changes in their tariff rates and the import/GDP ratios. An asterisk sign indicates that the data on capital intensity and current account are also available.

To control the effects of capital account opening on the current account, we adopt three capital account openness indices commonly used in the literature. The first is the Capital Control Index proposed by Fernandez, Klein, Rebucci, Schindler, and Uribe (2015). It measures the restrictions on inflows and outflows of ten categories of assets for 100 countries during 1995-2013. The second is the Wang-Jahan Capital Account Openness Index from the IMF, based on transaction restrictions on 12 types of assets for 168 countries during 1996-2013. The third is the Chinn-Ito Index, which covers 181 countries from 1970 to 2005.

The last three columns in Table 1 document the changes in capital account opening for each trade-reform episode according to each of the three capital account openness measures. It is denoted as "Open" if the capital account becomes more open, "Close" if it becomes less open, and "Unchanged" if there is no change. A slash sign indicates a lack of information. We see no systematic correlation between trade reforms and capital account reforms. There is little progress in capital account opening in most cases according to the Chinn-Ito Index. (Note that financial opening can still take place outside the trade reform episodes.)

We then perform the following simple regression:

$$
\Delta\left(\frac{C A_{j}}{G D P_{j}}\right)=\alpha+\beta \Delta k_{j}+\theta X_{j}+\varepsilon_{j}
$$

\footnotetext{
${ }^{5}$ This assumption might overlook potential pre-shock trends or demand shocks that may alter the capital intensity. However, as we focus on the change in aggregate capital intensity before and after trade reform, time-invariant heterogeneity across countries is not important.
} 
where $\Delta\left(\frac{C A_{j}}{G D P_{j}}\right)$ and $\Delta k_{j}$ represent the change in country j's current account to GDP ratio, and the change in the average capital intensity of its export bundle, respectively, while $X_{j}$ is a set of control variables including the change in financial openness and the change in the real exchange rate.

In Column 1 of Table 2, we report the basic regression result. The regression shows a negative and statistically significant relationship between the change in capital intensity and the change in current account. In other words, in episodes in which a trade policy change has led to a decline in the capital intensity of the country's exports (e.g., China after the WTO accession in 2002-2003), the current account balance tends to go up. Conversely, in episodes in which a trade policy change has led to an increase in capital intensity (such as India during 2005-2008), the current account balance tends to deteriorate.

In Column 2, we add the change in a country's real exchange rate over the same period of the trade policy change as a control variable. Because price (or inflation) information is missing for several countries in the sample, the regression sample is reduced to only 13 countries. In any case, the coefficient on the real exchange rate is negative and statistically significant, suggesting that a rise in the real exchange rate tends to be associated with a decline in a country's current account. Importantly, we continue to find a negative coefficient on capital intensity: a rise in a country's capital intensity tends to be associated with a deterioration in its current account.

In Columns 3-5, we include changes in capital account openness, measured, respectively, by the three indicators for capital account openness. It turns out that none of the capital account indicators is statistically significant. In other words, there is no statistical support for the hypothesis that an improved capital account openness leads to more capital outflow during the trade reform episodes.

Barattieri $(2014,2018)$ argues that the tariff reduction on goods trade would increase the trade surplus for those countries with a comparative advantage in manufacturing production, but produce an opposite change for those countries with a comparative advantage in the service sector. To account for this possibility, we construct a Revealed Comparative Advantage (RCA) index for manufacturing and services production, respectively, for each country in our sample, using the method in Barattieri (2018) and the merchandise and service trade flows data from the WTO world trade database. As shown in Columns (6)-(7) 
of Table 2, we add the initial RCA in manufacturing sectors (i.e., in the first year of a trade reform episode) and the initial RCA in service sectors, respectively. There is support for the hypothesis that those countries with a strong RCA in manufacturing production tend to experience an improvement in the current account following trade reforms. Importantly, after controlling for the initial RCA, our results remain robust. Indeed, the capital intensity variable becomes more significant: those countries with a decline in the capital/labor ratio after a trade reform tend to exhibit an improvement in their current account. These patterns are consistent with the prediction of the dynamic Stolper-Samuelson theorem that we will develop in the next section.

While our sample consists of the universe of all major trade reforms since 1990, it is still a relatively small sample. As such, we are not able to have many control variables. We also do not investigate the potential endogeneity of the regressors. We, therefore, treat the empirical results as suggestive data patterns rather than definitive empirics. In the rest of the paper, we aim to provide a theory that is consistent with these patterns in the data.

\section{The Basic Model}

Our model, in a nutshell, marries a Heckscher-Ohlin structure (with two tradable sectors of different factor intensities) and a small open-economy intertemporal framework. Importantly, we also incorporate an endogenous discount factor (EDF) following Uzawa (1968), Obstfeld (1982), Mendoza (1991), Uribe (1997), Schmitt-Grohe (1998), and Choi, Mark, and Sul (2008), among others. The EDF has a built-in "keeping-up-with-the Joneses" feature - an economic agent tends to become more patient when others in the economy are more patient, and vice versa. Philosophically, this strikes us as having captured a realistic feature of the world that is especially relevant when it comes to topics related to savings and consumption.

As noted earlier, the introduction of an endogenous discount factor helps us to address an inherent tension between the static HO trade model and the standard intertemporal framework. In the standard intertemporal model of current account, the interest rate in the steady state is determined by the (constant) discount factor from the demand side. In the static HO model, if the economy is within the diversification cone, the interest rate is determined by the zero-profit conditions from the supply side (i.e., the interest rate and 
the wage are completely determined by goods prices and tariff rates). In general, the two interest rates are inconsistent with each other except by coincidence. Even if one assumes that the two are the same initially, a permanent shock such as trade liberalization would cause the two implied interest rates to diverge again. However, with an endogenous discount factor, the problem of interest rate over-determination disappears. If a tariff change causes the interest rate to change due to the zero-profit conditions, the total consumption simply adjusts to accommodate that. It is useful to point out that the role of the endogenous discount factor here is not to provide stationarity to the model. There will be a small cost of adjusting the international bond holding which will provide stationarity as in the standard literature.

An endogenous discount rate means a discount rate that varies over time, for example, as a function of the economy-wide consumption per capita and income per capita. An individual may become more impatient when the average level of consumption in the economy goes up. In other words, people pay attention to status competition, where status is defined either by one's consumption relative to an economy-wide average or by one's own past consumption. This arguably captures a realistic aspect of human nature. Once we recognize this feature (and represent it in the utility function), we can resolve some seemingly puzzling features in models that impose a constant subjective discount rate. Uzawa (1968), which first introduced the concept of an endogenous discount factor in the literature, noted that a constant subjective discount rate and a constant interest rate would produce an unrealistic scenario in which the consumer would either save all the income or save nothing, except for the knife-edge case in which the subjective discount rate is equal to the interest rate. Uzawa shows that an endogenous discount factor would produce a more realistic scenario that gets away from the two extreme cases.

Obstfeld (1981) developed the first open-economy macro model that has incorporated an endogenous discount rate (but without HO features). In his model, the accumulation of external assets attains a stationary state when the (endogenous) discount rate reaches the level of an (exogenous) world interest rate. The endogenous discount rate ensures the existence of a stable perfect foresight equilibrium path that converges to the stationary state. Another important paper with an endogenous discount rate (but no HO features) is an open-economy real business cycles model developed by Mendoza (1991). That model 
produces a well-defined stationary equilibrium in an economy's holdings of foreign assets. In both open economy models, the endogenous discount rate is deployed to achieve stationarity. Neither model encounters this type of interest rate over-determination problem that we will describe below.

Epstein (1983) argued that an endogenous discount rate is a natural feature in a world with uncertain future incomes, and helps to ensure that consumption in every period is a normal good. Other papers have demonstrated that an endogenous discount rate can help resolve other seemingly puzzling observations such as a low real interest rate when the government spending is high (Devereux, 1991) or no country owns all the wealth in the world even if some countries are more patient initially (Daniel, 1997).

In short, an endogenous discount factor has a long intellectual history and has been found useful in understanding many macroeconomic phenomena including the dynamics of current account or foreign asset holdings. Our paper is the first that combines an endogenous discount factor with a dynamic HO model. By resolving the interest rate over-determination problem, this makes it possible for us to study the effects of a permanent shock to trade costs on the current account.

While interest rate over-determination is a unique problem to the dynamic HO framework, another technical challenge is common for small open economy models. This is the stationarity problem. As domestic residents have only access to a risk-free bond whose rate of return is exogenously determined abroad, the steady-state of the model depends on the country's initial net foreign asset position. This causes the equilibrium dynamics to possess a random walk component. This problem arises mainly because, in the steady state, the standard Euler equation is not sufficient to pin down the equilibrium. Schmit-Grohe and Uribe (2003) have reviewed the literature and proposed several alternative solutions, including a bond adjustment cost. We adopt a bond adjustment cost in our model.

In a standard model without $\mathrm{HO}$ features, either an endogenous discount factor or a bond adjustment cost is sufficient to solve the stationarity problem. However, in our setup, we cannot use an endogenous discount factor to address both the stationarity problem and the over-determination of the interest rate. Instead, we will have both an endogenous discount factor and costly bond adjustment. ${ }^{6}$

\footnotetext{
${ }^{6}$ The interest rate over-determination problem exists regardless of if there is an international bond. This problem would not go away if there is a cost of adjustment in the bond market. On the other hand,
} 


\subsection{Household}

The economy is inhabited by a continuum of identical and infinitely lived households that can be aggregated into a representative household. The representative household's preference over consumption flows is summarized by the following time-separable utility function

$$
U=\sum_{s=t}^{\infty} \theta_{s} U\left(C_{s}\right)
$$

where $C_{s}$ is the household's consumption of a final good at date $s$, and $\theta_{s}$ is the discount factor between period 0 and $s$ as given by

$$
\theta_{s+1}=\beta\left(\tilde{C}_{s}, \widetilde{Y}_{s}\right) \theta_{s}, s \geq 0
$$

where $\theta_{0}=1$ and $\frac{\partial \beta\left(\tilde{C}_{s}\right)}{\partial \tilde{C}_{s}}<0$ and $\frac{\partial \beta\left(\tilde{Y}_{s}\right)}{\partial \tilde{Y}_{s}}>0$. We assume that the endogenous discount factor does not depend on the household's own consumption and income, but rather on the economy-wide average per capita consumption $\tilde{C}_{s}$ and income $\tilde{Y}_{s}$, which the representative household takes as given. The exact functional form of $\beta\left(\tilde{C}_{s}, \tilde{Y}_{s}\right)$ will be presented later when we solve the model. The household owns both factors of production, capital $K$ and labor $L$. For simplicity, we assume a fixed labor supply.

The final good is produced by combining two intermediate goods. Each intermediate good is produced by combining capital and labor. The household supplies labor to both intermediate good sectors through a competitive spot market. In the benchmark model, both labor and capital are assumed to be freely mobile across sectors. Factor market frictions will be discussed later. The household can hold foreign asset $B_{t}$ to smooth consumption. Following Neumeyer and Perri (2005), we assume that trade in foreign bonds is subject to small and convex portfolio adjustment costs. If the household holds an amount $B_{t+1}$, then these portfolio adjustment costs, denominated in units of the final good, are $\frac{\psi_{b}}{2}\left(B_{t+1}-\bar{B}\right)^{2}$, where $\bar{B}$ is an exogenous capacity level of foreign asset management. For simplicity, we assume $\bar{B}=0$ in the analytical model.

Therefore, the budget constraint and the capital accumulation equation faced by the representative household are given, respectively, by

the problem is solved if $\beta$ is endogenous as we assume in the paper. A technical appendix provides more explanation on this point. 


$$
\begin{gathered}
P_{t}\left[C_{t}+\frac{\psi_{b}}{2}\left(B_{t+1}-\bar{B}\right)^{2}\right]+B_{t+1}+I_{t} \\
=w_{t} L+r_{t} K_{t}+\left(1+r^{*}\right) B_{t}+T R_{t} \\
K_{t+1}=(1-\delta) K_{t}+I_{t}-\frac{1}{2} \psi_{k}\left(\frac{I_{t}}{K_{t}}-\delta\right)^{2} K_{t}
\end{gathered}
$$

where $I_{t}$ is investment in period $t$, and $w_{t}$ and $r_{t}$ are the wage and the domestic return to capital, while $r^{*}$ is the world interest rate. $\delta$ is the capital appreciation rate and $\psi_{k}$ is the aggregate capital adjustment cost coefficient. The tariff revenue, $T R_{t}$ is rebated in a lump sum to the representative consumer, which is taken as exogenous by the consumer. ${ }^{7}$

The first order conditions with respect to $C_{t}, I_{t}, K_{t+1}$, and $B_{t+1}$, are, respectively,

$$
\begin{gathered}
\frac{U_{c}^{\prime}\left(C_{t}\right)}{P_{t}}=\Omega_{t} \\
\Lambda_{t}\left(1-\psi_{k}\left(\frac{I_{t}}{K_{t}}-\delta\right)\right)=\Omega_{t} \\
\Lambda_{t}=\beta\left(\tilde{C}_{t}, \widetilde{Y}_{t}\right)\left[\Lambda_{t+1}\left(1-\delta+\frac{\psi_{k}}{2}\left(\frac{I_{t+1}}{K_{t+1}}-\delta\right)\left(\frac{I_{t+1}}{K_{t+1}}+\delta\right)\right)+\Omega_{t+1} r_{t+1}\right] \\
\Omega_{t}\left[1+\psi_{b} P_{t}\left(B_{t+1}-\bar{B}\right)\right]=\beta\left(\tilde{C}_{t}, \tilde{Y}_{t}\right)\left[\Omega_{t+1}\left(1+r^{*}\right)\right]
\end{gathered}
$$

where $\Omega_{t}$ and $\Lambda_{t}$ are Lagrangian multipliers for the budget constraint and the law of motion for capital, respectively.

\subsection{Production}

The production function for the final good is $D_{t}=G\left(D_{1 t}, D_{2 t}\right)$, where $D_{i t}$ is the usage of intermediate good $i$ by the final good producer. The production function for the intermediate good $i(=1,2)$ is $X_{i t}=f_{i}\left(A_{i t} L_{i t}, K_{i t}\right)$ where $A_{i t}$ measures labor productivity. $A_{i t} L_{i t}$ can be understood as units of effective labor. All production functions are assumed to be

\footnotetext{
${ }^{7}$ See Devereux and Lee (1999) for a similar assumption.
} 
homogeneous of degree one. $D_{i t}$ and $X_{i t}$ can differ due to international trade.

The unit cost function for $X_{i t}$ is $\phi_{i}\left(\frac{w_{t}}{A_{i t}}, r_{t}\right)$. Let $P_{i}$ be the domestic price of intermediate good $i$. We assume that the country's endowment is always within the diversification cone so that both intermediate goods are produced. In each period $t$, free entry and zero profits in both the intermediate good and the final good markets imply that

$$
\begin{gathered}
P_{1 t}=\phi_{1}\left(\frac{w_{t}}{A_{1 t}}, r_{t}\right), P_{2 t}=\phi_{2}\left(\frac{w_{t}}{A_{2 t}}, r_{t}\right) \\
P_{t} D_{t}=P_{t} G\left(D_{1 t}, D_{2 t}\right)=P_{1 t} D_{1 t}+P_{2 t} D_{2 t}
\end{gathered}
$$

\subsection{Equilibrium}

In equilibrium, trade in intermediate goods equalizes (tariff-inclusive) good prices between the home country and the rest of the world in every period. Without loss of generality, we assume that sector 1 is labor-intensive while sector 2 is capital-intensive. Considering a labor abundant country which exports labor intensive good 1, we have:

$$
P_{1 t}=P_{1 t}^{*}, P_{2 t}=(1+\tau) P_{2 t}^{*},
$$

where $P_{i t}^{*}$ denotes the world price and is exogenously given, and $\tau$ is the import tariff. Following the standard assumptions in the Hecksher-Ohlin model, we assume that production functions (and unit cost functions) in all countries are the same (although labor-augmenting productivity can be different). Therefore, in the foreign country we also have:

$$
P_{1}^{*}=\phi_{1}\left(\frac{w^{*}}{A_{1}^{*}}, r^{*}\right), P_{2}^{*}=\phi_{2}\left(\frac{w^{*}}{A_{2}^{*}}, r^{*}\right)
$$

For simplicity, we assume that the rest of the world is in steady state so the return to capital, $r^{*}$, is a constant. We will leave out the time subscript for all foreign variables from now on. We have the following market clearing conditions in the home country

$$
\begin{aligned}
& K_{t}=K_{1 t}+K_{2 t} \\
& L_{t}=L_{1 t}+L_{2 t}
\end{aligned}
$$




$$
D_{t}=C_{t}+\frac{I_{t}}{P_{t}}+\frac{\psi_{b}}{2}\left(B_{t+1}-\bar{B}\right)^{2}
$$

Equation (3.16) implies that the final good is used not only for consumption and investment, but also for covering the costs of adjusting the international asset position. The current account balance over period $t$ is defined as $C A_{t}=B_{t+1}-B_{t}$; thus, noting that $P_{i t} X_{i t}=w_{t} L_{i t}+r_{t} K_{i t}$ and using equations (3.11) and (3.16), we can rewrite the budget constraint as

$$
C A_{t}=P_{1 t}^{*}\left(X_{1 t}-D_{1 t}\right)+P_{2 t}^{*}\left(X_{2 t}-D_{2 t}\right)+r^{*} B_{t}
$$

That is, the current account balance is equal to the trade balance (evaluated at the world prices) plus the interest income from the net foreign asset position. For future reference, we define the gross domestic product as $Y_{t}=\frac{P_{1} X_{1 t}+P_{2} X_{2 t}}{P_{t}}$.

\section{Equilibrium Analysis}

To study the equilibrium explicitly, we adopt the following standard functional forms for preference and technology. The utility function is $U\left(C_{t}\right)=\frac{C_{t}{ }^{1-\gamma}}{1-\gamma}$, where $\gamma$ is the inverse of the elasticity of intertemporal substitution. The production function for the final good is $G\left(D_{1 t}, D_{2 t}\right)=\frac{1}{\omega^{\omega}(1-\omega)^{1-\omega}} D_{1 t}^{\omega} D_{2 t}^{1-\omega}$, where $\omega$ is the expenditure share on good $D_{1}$ in the final good production. The production function for good $i$ is $f_{i}\left(A_{i t} L_{i t}, K_{i t}\right)=$

$\frac{1}{\alpha_{i}^{\alpha_{i}}\left(1-\alpha_{i}\right)^{1-\alpha_{i}}} K_{i t}^{\alpha_{i}}\left(A_{i t} L_{i t}\right)^{1-\alpha_{i}}$, where $\alpha_{i}$ is the capital share in producing intermediate good $i$. We let $\alpha_{1}<\alpha_{2}$ so that sector 1 is labor intensive. The endogenous discount factor takes the following function form:

$$
\beta\left(\tilde{C}_{t}, \widetilde{Y}_{t}\right)=\beta\left(\frac{\tilde{C}_{t}}{\bar{C}}\right)^{-\psi_{1}}\left(\frac{\tilde{Y}_{t}}{\bar{Y}}\right)^{\psi_{2}}
$$

where $\psi_{1}>0$ and $\psi_{2}>0 . \bar{C}$ and $\bar{Y}$ are, respectively, the average consumption and output levels in the initial steady state with tariff $\tau_{0}$. This form is a variant of Choi, Mark, and Sul (2008). When the economy-wide average consumption $\tilde{C}_{t}$ falls relative to the initial steady state value, the representative agent becomes more patient. That is the implication of this type of discount factor. In the new steady state after a tariff reform, the endogenous discounted factor would deviate from the constant $\beta$. To make the model parsimonious, we 
assume $\psi_{1}=\psi_{2}=\psi$.

\subsection{The Effects of Trade Liberalizations}

For simplicity, we assume that $A_{1}^{*}=A_{2}^{*}=1$. In equilibrium, given the production functions, from Equation (3.10), we have

$$
\left(\frac{w_{t}}{A_{1 t}}\right)^{1-\alpha_{1}} r_{t}^{\alpha_{1}}=P_{1}^{*},\left(\frac{w_{t}}{A_{2 t}}\right)^{1-\alpha_{2}} r_{t}^{\alpha_{2}}=(1+\tau) P_{2}^{*}
$$

which give

$$
\begin{gathered}
r_{t}=r^{*}\left[\left(\frac{A_{1 t}}{A_{2 t}}\right)^{\left(1-\alpha_{1}\right)\left(1-\alpha_{2}\right)} \frac{1}{(1+\tau)^{\left(1-\alpha_{1}\right)}}\right]^{\frac{1}{\alpha_{1}-\alpha_{2}}} \\
w_{t}=w^{*}\left[\frac{A_{1 t}^{\left(1-\alpha_{1}\right) \alpha_{2}}}{A_{2 t}^{\alpha_{1}\left(1-\alpha_{2}\right)}} \frac{1}{(1+\tau)^{\alpha_{1}}}\right]^{\frac{1}{\alpha_{2}-\alpha_{1}}}
\end{gathered}
$$

Three comparative statics can be immediately seen: (a) $\frac{\partial r_{t}}{\partial \tau}>0$, (b) $\frac{\partial r_{t}}{\partial A_{1 t}}<0$, and (c) $\frac{\partial r_{t}}{\partial A_{2 t}}>0$. By inequality (a), trade liberalization in a labor-abundant country (a reduction in $\tau)$ reduces the return to capital. Inequalities (b) and (c) pertain to sector-biased productivity shocks. While technological progress in the labor-intensive sector reduces the return to capital, the same change in the capital-intensive sector produces the opposite effect. It can be verified that as long as there is faster technology progress in the labor-intensive sector relative to the capital-intensive sector $\left(\frac{A_{1 t}}{A_{2 t}}\right.$ increases$)$, the return to capital declines.

These results (in a dynamic setting) are consistent with the Stolper-Samuelson theorem in a static HO model. That is, an increase in the price of a good increases the return to the factor used more intensively in that good, and reduces the return to the other factor. A tariff reduction in the capital intensive sector implies a decrease in the price of capital intensive goods, therefore, $r_{t}$ decreases but $w_{t}$ increases. $^{8}$

It is worth emphasizing that the discussion points to a natural asymmetry between

\footnotetext{
${ }^{8}$ The current model assumes that the economy always stays in the diversification cone. In our quantitative exercise, with reasonable parameter values and realistic shocks, the economy continues to stay inside the diversification cone. Following Reyes-Heroles, Traiberman, and Van Leemput (2020), we may modify the model to rule out full-specialization equilibria by introducing heterogeneous firms and an Eaton-Korum structure in each sector.
} 
developed (capital abundant) and developing (labor abundant) countries. Trade liberalizations tend to reduce the domestic return to capital for a developing country but to raise it for a developed country.

\subsubsection{Net Foreign Asset Positions}

We consider two cases of the effects on net foreign asset positions, $B_{t}$. First, in the transitional dynamics, we assume that the investment adjustment cost $\psi_{k}$ is zero. Using equations (3.7), (3.8) and (3.9), we obtain:

$$
B_{t+1}=\frac{1}{\psi_{b} P_{t}} \frac{r^{*}-r_{t+1}+\delta}{1+r_{t+1}-\delta}
$$

The holding of foreign bond $B_{t+1}$ is a function of $r_{t+1}$ and $\frac{\partial B_{t+1}}{\partial r_{t+1}}<0$. Second, in the steady state, using first order conditions (3.7), (3.8) and (3.9), we obtain:

$$
B=\frac{1}{\psi_{b} P} \frac{r^{*}-r+\delta}{1+r-\delta}
$$

That is, when the return to capital in the country decreases, capital flows out so that the net foreign asset increases in the steady state. Note that the result for net foreign asset positions does not depend on the assumption of an endogenous discount factor, $\beta\left(\tilde{C}_{t}, \tilde{Y}_{t}\right)$. For any form of discount factor (endogenous or exogenous), the net foreign asset position must increase if the domestic interest rate declines. We summarize our discussion by the following proposition:

Proposition 1 A trade liberalization, or a reduction in trade costs, in a labor abundant country leads to a decrease in the return to capital in the country, which results in an increase in foreign asset holding in the steady state. Technological progress in favor of the comparative advantage sector in a labor abundant country also reduces the return to capital and produces an increase in the net foreign asset position. An opposite set of results holds when a trade liberalization, a reduction in trade costs, or a productivity increase in favor of the comparative advantage sector, take places in a capital abundant country. ${ }^{9}$

\footnotetext{
${ }^{9}$ Let $t_{c}$ be the iceberg trade cost, we will have: $P_{1 t}=\frac{P_{1}^{*}}{1+t_{c}}$ and $P_{2 t}=\left(1+t_{c}+\tau\right) P_{2}^{*}$. It is immediately seen that a reduction in trade cost will increase the price of the labor-intensive good, $P_{1 t}$, but reduce $P_{2 t}$.
} 


\subsubsection{Steady State}

Using the Euler equation in the steady state (3.8) and the function of endogenous discount factor (4.18), we solve for the ratio of consumption to income.

$$
c_{y}=\frac{\bar{C}}{\bar{Y}}[\beta(1+r-\delta)]^{\frac{1}{\psi}}
$$

where $c_{y}=\frac{C}{Y} . \bar{C}$ and $\bar{Y}$ are the consumption and income level in the initial steady state, respectively. Clearly, $\frac{\partial c_{y}}{\partial r}>0$. Note that the interest rate is determined by the production side (along the demand curve of capital). A decrease in the interest rate implies that the combined size of capital stock and foreign asset holding in the new steady state is larger, which requires that the household becomes more patient and consumes less relative to income.

The return to factors $(r, w)$ and the holding of foreign asset $(B)$ are given by equations (4.20), (4.21) and (4.23). Given that, we can solve for the demand for the final good, $D$, consumption, $C$, investment, $I$, Gross Domestic Product, $Y$ and sectoral outputs $X_{1}$ and $X_{2}$ from the set of equations listed in Appendix 7.1. We can write the sectoral outputs as below

$$
\begin{aligned}
P_{1} X_{1} & =\frac{w L-\left(1-\alpha_{2}\right)(1+\tau)\left(\zeta P D-r^{*} B\right)}{\left(1-\alpha_{1}\right)-(1+\tau)\left(1-\alpha_{2}\right)} \\
P_{2} X_{2} & =\frac{\left(1-\alpha_{1}\right)(1+\tau)\left(\zeta P D-r^{*} B\right)-(1+\tau) w L}{\left(1-\alpha_{1}\right)-(1+\tau)\left(1-\alpha_{2}\right)}
\end{aligned}
$$

where $\zeta=\omega+\omega /(1+\tau)$. The optimization conditions for the final good producer yield $P_{1} D_{1}=\omega P D$. Thus the exports of intermediate good 1 are given by

$$
N X_{1}=P_{1}\left(X_{1}-D_{1}\right)=P_{1} X_{1}-\omega P D
$$

Similar to the analysis of the tariff reduction, a reduction in trade cost will result in a decrease in $r$. On the other hand, if the home country were a capital abundant country and exporting good 2, we would have $P_{2 t}=\frac{P_{2}^{*}}{1+t_{c}}$ and $P_{1 t}=\left(1+t_{c}+\tau\right) P_{1}^{*}$. Now a reduction in tariff or trade cost would reduce the price of the labor-intensive good, $P_{1 t}$, but increase $P_{2 t}$, which would increase $r$. 
Finally, the factor usages and capital intensities in sector $i$ are given by

$$
\begin{aligned}
K_{i} & =\alpha_{i} \frac{P_{i} X_{i}}{r}, L_{i}=\left(1-\alpha_{i}\right) \frac{P_{i} X_{i}}{w}, \text { and } \\
\frac{K_{i}}{L_{i}} & =\frac{\alpha_{i}}{1-\alpha_{i}} \frac{w}{r}
\end{aligned}
$$

A tariff cut in the capital intensive sector will lead to an expansion of the labor-intensive sector, and a contraction of the capital-intensive sector. As a result, labor and capital flow from the capital-intensive sector to the labor-intensive sector, and both exports and imports go up.

\subsection{Calibrations in the Basic Model}

To calibrate the basic model, we follow the standard approach (as in Backus, Kehoe, and Kydland, 1992, 1994; and Kehoe and Perri, 2002) as much as possible. The parameter values are summarized in Table 3 . We set the steady state discount factor $\beta=0.99$, which implies a 4 percent annual world interest rate. The inverse of the elasticity of intertemporal substitution $\gamma=2$, which is also widely used in the literature. We assume an equal share of the intermediate goods in the final good production, so $\omega=0.5 .^{10}$ We choose $\alpha_{1}=0.33$ and $\alpha_{2}=0.7$ so that both the average labor share and the average dispersion of the labor shares in the model economy are the same as those estimated from China's input-output Table in 2002. ${ }^{11}$ We set capital adjustment cost $\psi_{k}=4$ in the benchmark so the elasticity of Tobin's $\mathrm{Q}$ with respect to the investment capital ratio is 0.1 , which is within the range reported in the literature. This parameter only affects the dynamic path, in the quantitative analysis, we vary the value of $\psi_{k}$ for robustness check. We set the annual depreciation rate of capital at $10 \%$, which implies $\delta=0.025$.

\footnotetext{
${ }^{10}$ From the Chinese Input-Output Table, we can obtain the domestic consumption of each industry, which is the sum of consumption of private sector and government sector. The ratio of consumption from exporting industry to consumption from importing industry is close to 1.03 . For simplicity, we set $\omega=0.5$.

${ }^{11}$ In the Chinese firm-level data, for labor compensation, the firms only report wage payments; they do not provide information on non-wage compensation. The median labor share in plant-level data is roughly $30 \%$, which is significantly lower than the aggregate labor share in the national accounts (roughly 50\%). Following Hsieh and Klenow (2009), we, therefore, assume that non-wage benefits are a constant fraction of a plant's wage compensation, where the adjustment factor is calculated such that the sum of imputed benefits and wages across all plants equals $50 \%$ of aggregate value-added.
} 
Table 3: Parameter Values in Calibration

\begin{tabular}{|l|l|r|}
\hline$\beta$ & discount factor in steady state & 0.99 \\
\hline$\gamma$ & inverse of the elasticity of intertemproal substitution & 2 \\
\hline$\alpha_{1}$ & capital share in sector 1 & 0.33 \\
\hline$\alpha_{2}$ & capital share in sector 2 & 0.7 \\
\hline$\omega$ & share of good 1 in final good & 0.5 \\
\hline$\delta$ & capital depreciation rate & 0.025 \\
\hline$\psi_{k}$ & capital adjustment cost & 4 \\
\hline$\psi_{b}$ & bond adjustment cost & 0.0063 \\
\hline$\psi$ & parameter of endogenous discount factor & 0.0688 \\
\hline$t_{c}$ & initial trade cost & 0.1 \\
\hline$\tau$ & initial import tariff & 0.15 \\
\hline$\tau^{s s}$ & import tariff in new steady state & 0.1 \\
\hline$A_{1}^{0}$ & initial productivity for sector 1 & 0.0546 \\
\hline$A_{2}^{0}$ & initial productivity for sector 2 & 0.0225 \\
\hline$A_{1}^{s s}$ & productivity for sector 1 in new steady state & 0.1028 \\
\hline$A_{2}^{s s}$ & productivity for sector 2 in new steady state & 0.0250 \\
\hline
\end{tabular}

We set $t_{c}=0.1$, which implies that the trade cost for both exports and imports equals $10 \%$ of the total trade value. This estimate is based on the difference between the CIF (cost, insurance and freight) and FOB (free on board) values of trade flows reported by the custom authorities. The difference varies across trading partners, and $10 \%$ is close to the weighted average with bilateral trade volume as the weights.

For the initial steady state, we assume that $15 \%$ tariff is imposed on the capital intensive sector, and the ratio of foreign asset position to GDP $(\bar{B} / \bar{Y})$ and the ratio of consumption to GDP $(\bar{C} / \bar{Y})$ equal to their corresponding values in 2000 , respectively. To back out the values of the two parameters, we use the following information: China's export share in GDP in 2000 is approximately 10\%, and China's aggregate TFP level relative to that of the world in 2000 from the Penn World Table is 0.36 .

For the new post-reform steady state, we allow $B$ and $C / Y$ to deviate from $\bar{B}$ and $\bar{C} / \bar{Y}$, respectively. The import tariff is reduced to $10 \%$ and the trade cost in the export sector 
is reduced to $0.08 .^{12}$ The steady state is jointly determined by four parameters: $\psi_{b}, \psi$, $A_{1}^{s s}$ and $A_{2}^{s s}$. To calibrate their values, we use the following information. First, China's aggregate TFP relative to the rest of the world in 2007 is 0.51 (from the Penn World Table 9.1). Second, the ratio of total consumption (both private and government) to GDP in 2007 is about $60 \%$ (from the Penn World Table 9.1). Third, the capital rent declined by 1.1 percentage points from 2000 to 2004 (from the Penn World Table 9.1). Fourth, China's foreign asset position as a share of GDP in 2007 is $29 \%$.

We consider two policy experiments: a reduction in the tariff rate by 5 and 10 percentage points, respectively. In columns 2,3 , and 4 of Table 4 , we report the values for both the initial steady state (when the tariff=15\%) and the new steady states (when the tariff $=$ $10 \%$ and $5 \%$, respectively $)^{13}$. The price variables, aggregate quantity variables, sectoral variables, and balance-of-payments (BOP) variables are organized in four panels.

The results confirm Proposition 1 . In particular, the return to capital, $r_{1}=r_{2}$, declines while the wage rate, $w_{1}=w_{2}$, rises. In the new steady state after the tariff cut, aggregate consumption $C$, investment $I$, and GDP $Y$ all increase. The labor-intensive sector (Sector 1) expands so that $K_{1}, L_{1}$, and $X_{1}$ all increase, while the capital intensive sector (Sector 2) contracts. Both exports $\left(N X_{1}\right)$ and imports $\left(-N X_{2}\right)$ expand. The trade volume to GDP ratio, $T V / G D P$, increases by 2.1 percentage points. Most interestingly, the exports expand faster than the imports, and capital flows out of the country so that the cumulative increase in the foreign asset holding reaches $22 \%$ of GDP. In other words, a relatively moderate tariff reduction (from $15 \%$ to $10 \%$ ) results in a significant capital outflow.

In the second policy experiment, a more substantial (but still realistic) tariff reduction by 10 percentage points (from $15 \%$ to $5 \%$ ) leads to an even greater increase in foreign asset holdings to $32.8 \%$ of GDP.

There are also interesting by-products of the trade reforms. In particular, consumption as a share of GDP declines while the investment to GDP ratio increases. To be precise, both

\footnotetext{
${ }^{12}$ The reduction in the export cost is motivated by the removal of tariff uncertainty in the United States after the US granted permanent normal trading relations (PNTR) to China in 2000. Handley and Limao (2016) estimated that the PNTR reform is equivalent to a permanent reduction in the US tariff rate on imports from China by 13 percentage points (on mostly labor-intensive products). From 2001-2007, the Chinese exports to the US are about 15 percent of China's total exports on average. Therefore, we assume that the PNTR reform is equivalent to a reduction on Chinese export cost by 2 percent.

${ }^{13}$ In the benchmark case, the sectoral productivity in both sectors and the trade cost remain unchanged at their initial steady state level.
} 
consumption and output expand from the old to the new steady state (see the row labeled as "C" in Table 4), so the decline in the ratio of consumption to GDP comes from uneven speeds of expansion, not from a decline in consumption in the steady level. This is an interesting bonus finding. Chinese data in recent years exhibit a declining ratio of consumption to GDP, and it is commonly interpreted to be a result of some policy distortions (either exchange rate manipulation or financial repression). Our calibration generates such a feature as a result of a reduction in policy distortions (tariffs).

In Figure 2, we report the dynamic paths of the economy from the initial to the new steady state after a 5 percentage points cut in the tariff (from $15 \%$ to $10 \%$ ). We assume that the trade liberalization starts to hit the economy in period 1 . We find that the structural adjustment takes place immediately. In particular, sector 1 (the labor-intensive sector) expands immediately with an increase in $K_{1}, L_{1}$, and $X_{1}$, while sector 2 contracts immediately, with a decline in $K_{2}, L_{2}$, and $X_{2}$. As a result, both the export share $s x$ and import share $-s m$ increase immediately. As noted, the consumption response is interesting. After a decline in the first several periods, consumption rises gradually. Intuitively, because the domestic return to capital declines after the trade reform, the endogenous discount factor specification implies that the representative household must become more patient. This in turn causes the household to have a lower ratio of consumption/income (or a higher savings rate) both during the transition and in the new steady state. (It is important to reiterate that we can see, from Table 4, that the absolute level of consumption does go up in the new steady state. In other words, trade reforms do raise consumption, but not the ratio of consumption to GDP.)

In Figure 3, we report the dynamic paths for some key balance-of-payments items. From the top-left graph, we observe that the trade volume (the sum of exports and imports as a share of GDP) jumps immediately. This is not surprising as both imports and exports expand.

There are three ways of viewing a country's current account: (a) as net capital outflows, (b) as the sum of trade balance and net international factor payment, and (c) as the difference between national savings and national investment. In this case, thinking of the current account as net capital outflows turns out to be most convenient in terms of obtaining intuition for our result. Following a tariff cut (on capital intensive goods), Proposition 1 in 
Section 4.1.1 points out that the domestic return to capital would decline if all other things were held constant (including imposing a closed capital account). Of course, other things cannot be held constant. In particular, if the domestic return to capital falls, it immediately creates an incentive for capital outflow. This is why a current account surplus tends to follow a tariff reform that reduces the domestic price of the capital intensive goods. The thick line in the upper right graph traces out the trajectory of current account as a share of GDP which exhibits a positive current account for over 20 quarters before converging to zero. In our model economy, the bottom right graph shows that $B / G D P$ is hump-shaped in response to the tariff cut and increases gradually to the new steady state level (of $22 \%$ of GDP).

Of course, the other two ways of thinking about the current account also have to hold as a matter of identities. In the top right graph, the broken thin line traces the trade balance as a share of GDP. This variable jumps into a surplus immediately following the tariff cut, reaching somewhere around 4 percent of GDP, but goes into a deficit after about 20 quarters, since it has to offset the positive interest payment the country receives from its foreign asset holdings to produce a zero current account.

The identity that current account is the difference between national savings and investment is also respected. The trajectories for savings and investment as shares of GDP are plotted in the lower left graph. The savings rate goes up immediately after the trade reform, while the investment rate goes up slowly and reaches a peak at the 10th quarter. The gap between savings and investment is always equal to the current account indicated by the thick line in the upper right graph. Note that the domestic investment (as a share of GDP) can go either up or down, depending on the relative strengths of two opposite effects. First, in the face of a tariff cut, the return to capital declines, which leads to a rise in the capital-labor ratio in each sector and contributes to an increase in the aggregate investment; Secondly, the expansion of the labor intensive sector and the contraction of the capital intensive sector after the tariff cut generate a composition effect, which results in lower domestic demand for investment.

In Figure 4, we report the dynamic responses of the trade volume and the balance of payment to a simultaneous reduction of import tariff by 5 percentage points and of export costs by $2 \%$. With an additional cut in the export costs (the PNTR reform in the United 
States), the initial trade volume/GDP increases from $37 \%$ to $43 \%$, and the initial current account/GDP increases slightly from $3 \%$ to $3.7 \%$. For the foreign asset holdings in the new steady state, it increases from $22 \%$ to $24 \%$. The overall effect of the export cost reduction is quantitatively small relative to that of the tariff reduction. This is because the tariff reduction applies to all imports whereas the export cost reduction is only for the US market.

We now perform some sensitivity analysis. First, we investigate the transitional dynamics when we vary the parameter value of aggregate capital adjustment cost $\left(\psi_{k}=4\right.$, 8 , and 12, respectively.) The results are presented in the top row of Figure 5. Although the steady state is not affected by changes in $\psi_{k}$, the trade volume, the current account and the foreign asset position in the transition dynamics become (moderately) larger when $\psi_{k}$ becomes smaller. The overall dynamics of the balance of payments does not appear to be very sensitive to perturbations in the parameter value of aggregate capital adjustment costs.

Second, we investigate the BOP dynamics at different values of the bond adjustment cost. $^{14}$ In the second row of Figure 5, we report the transitional dynamics under the assumption of two alternative values of $\psi_{b}, 0.005$ and 0.008 , in addition to the benchmark value of 0.0063 . In all cases, the qualitative results stay the same. In particular, the country still runs a current account surplus after a tariff cut.

We then assess and compare the relative contributions of sectoral productivity changes, tariff cut, and export cost reduction to observed capital outflows for China during 2000-2007. The total capital outflow in the data is measured by the cumulative current account surplus during that period, which is about 18 percent of GDP. Table 5 summarizes simulation results.

\footnotetext{
${ }^{14}$ Note that as equation (4.22) indicates, when the investment adjustment cost $\psi_{k}$ is zero, the percentage change of $B_{t+1}, \frac{B_{t+1}-B_{t}}{B_{t}}$, does not depend on the bond adjustment cost $\psi_{b}$.
} 
Table 5: Contribution to Capital Outflow

\begin{tabular}{|l|c|r|c|}
\hline & Changes in Shocks & $\Delta \mathrm{B} / \mathrm{Y}$ & Contribution \\
\hline Data 2000-2007 & & 0.180 & \\
\hline Model & & & \\
\hline only TFP growth in Sector 1 & $+53 \%$ & 0.167 & $92.7 \%$ \\
\hline only TFP growth in Sector 2 & $+3 \%$ & -0.096 & $-53.3 \%$ \\
\hline TFP growth in Sector 1 \& 2 & $+53 \% \&+3 \%$ & 0.138 & $76.7 \%$ \\
\hline only Tariff Cut & $-5 \%$ & 0.113 & $62.8 \%$ \\
\hline only Export Cost reduction & $-2 \%$ & 0.020 & $11 \%$ \\
\hline
\end{tabular}

One important takeaway is a comparison of the effects of a trade reform versus a TFP increase on capital outflow. As shown in the table, the TFP increase in the export sector leads to capital outflow while the TFP increase in the import sector generates capital inflow. This is consistent with our theory. The net TFP effect can account for more than $76.7 \%$ of the capital outflow ${ }^{15}$. The tariff reduction and the lower export cost can explain 62.8 percent and 11 percent of the capital outflow, respectively. (Note that these effects do not add up to $100 \%$ due to interaction effects among them.) Quantitatively, trade reforms such as a tariff cut at home and the PNTR reform in the partner country are as important as a TFP change in explaining capital outflows.

\section{$5 \quad$ Factor Market Frictions}

Factor market reforms can affect how a country's current account responds to a given trade reform. Logically, factor market frictions that block or reduce the extent of the reallocation of factors across sectors can also block or reduce the current account response to trade reforms. We now turn to this topic. We start with financial frictions in the form of credit constraints.

\footnotetext{
${ }^{15}$ The sectoral TFP changes reported in Table is the cumulative change of TFP relative to foreign countries during 2000-2007. They are calculated by using data from Penn World Table 9.1.
} 


\subsection{Financial Frictions}

Following Antras and Caballero (2009), we make the simplifying assumption that financial frictions are asymmetric in the two sectors: while firms in the importing sector can employ any desired amount of capital at the equilibrium interest rate, firms in the exporting sector face credit constraints. Credit constraints are introduced through the following (admittedly artificial) setting. Each capitalist owns one unit of capital so that the capital stock $K$ is owned by a total $K$ of capitalists. A proportion $\xi$ of $K$ are endowed with "entrepreneurial ability" and labeled "entrepreneurs". Only the "entrepreneurs" know how to operate in the exporting sector. However, each entrepreneur can borrow only up to $\theta$ amount of her own capital. Thus the total amount of capital employed in the exporting sector is given by,

$$
K_{1 t} \leqslant(1+\theta) \xi K_{t}=\mu_{k} K_{t}
$$

where $\mu_{k}=(1+\theta) \xi$. We focus on the case in which financial frictions are binding (or $\mu$ is sufficiently small) so that $\mu_{k} K$ is less than the desired amount of capital that exporting firms would like to employ in the absence of financial frictions.

Let $r_{i}$ be the return to capital in sector $i$. The financial frictions cause a wedge between the returns to capital in the two sectors, $r_{1 t}>r_{2 t}$. The budget constraint (3.4) now is changed to

$$
\begin{aligned}
& P_{t}\left[C_{t}+\frac{\psi_{b}}{2}\left(B_{t+1}-\bar{B}\right)^{2}\right]+B_{t+1}+I_{t} \\
= & w_{t} L+\sum_{i=1}^{2} r_{i t} K_{i t}+\left(1+r^{*}\right) B_{t}+T R_{t}
\end{aligned}
$$

In addition to the capital accumulation equation, the representative household also faces the credit constraint (5.30) and capital market clearing condition, $K_{1 t}+K_{2 t}=K_{t}$. When the credit constraint (5.30) is binding, we have $K_{1 t}=\mu_{k} K_{t}$ and $K_{2 t}=\left(1-\mu_{k}\right) K_{t}$. Using these results, the budget constraint (3.4) now becomes: 


$$
\begin{aligned}
& P_{t}\left[C_{t}+\frac{\psi_{b}}{2}\left(B_{t+1}-\bar{B}\right)^{2}\right]+B_{t+1}+I_{t} \\
= & w_{t} L+\left[\mu_{k} r_{1 t}+\left(1-\mu_{k}\right) r_{2 t}\right] K_{t}+\left(1+r^{*}\right) B_{t}+T R_{t}
\end{aligned}
$$

Therefore, the first order conditions with respect to $C_{t}, K_{t+1}, B_{t+1}$, and $L_{i t}$ in the consumer's maximization problem now remain the same as conditions (3.6), (3.8), and (3.9) except that we now replace $r_{t+1}$ by

$$
r_{t+1}^{C}=\mu_{k} r_{1, t+1}+\left(1-\mu_{k}\right) r_{2, t+1}
$$

\subsubsection{The Steady-State Equilibrium}

The steady-state equilibrium in the case of financial frictions is represented by 15 equations with 15 variables, and is summarized in Appendix 7.3. Similar to equation (4.23), in the steady state we have

$$
B=\frac{1}{\psi_{b} P} \frac{r^{*}-r^{C}+\delta}{1+r^{C}-\delta}
$$

Thus, $r^{C}=\mu_{k} r_{1}+\left(1-\mu_{k}\right) r_{2}$, is a key variable in determining the country's net foreign asset holding $B$.

Because we are not able to obtain an analytical solution, we will resort to numerical results. Here we offer some intuition for the numerical results. In face of a tariff cut, the exporting sector is expected to expand while the import-competing sector shrinks. However, due to financial frictions, the exporting sector cannot expand as much. In such a case, the return to capital in the exporting sector, $r_{1}$, rises while that in the import-competing sector, $r_{2}$, declines. Therefore, the average return to capital, $r^{C}$, will decrease less than that in the case without financial frictions. From (5.34), we should observe a smaller $B$. That is, financial frictions impede the expansion of the exporting sector, a given trade reform produces a smaller capital outflow.

Several recent papers (Caballero, Farhi, and Gourinchas, 2008; Mendoza, Quadrini, and Rios-Rull, 2009; Ju and Wei, 2010; and Song, Storesletten, and Zilibotti, 2011) have shown that a low level of financial development in a developing country can produce a financial capital outflow to developed countries. Therefore, a tighter financial friction would lead to 
more current account surplus in a developing country. Our paper, however, suggests the opposite. When credit constraint is asymmetric across sectors, for example, when there is a credit rationing in one sector but not in another sector, similar to the setup in Antras and Caballero (2009), we show that a tighter credit constraint induces capital inflow (or a smaller current account surplus). The two parts of the literature can be reconciled when one realizes that the first set of papers emphasizes the effect of financial frictions on the supply side of capital (financial frictions reduce the return on savings and generate incentives to move savings out of the country), while the current paper and Antras and Caballero (2009) stress the demand side effect (credit constraints could increase demand for capital by firms in the unconstrained sector). Our model is different from Antras and Caballero (2009) in that trade liberalization always leads to capital outflow (current account surplus) under credit constraints, although the amount of capital outflow could be made smaller by a tighter credit constraint.

\subsection{Labor Market Frictions}

We can model labor frictions in a similar fashion and obtain qualitatively similar results. Assume that labor employed in the exporting sector requires "exporting skills", and the amount of labor with "exporting skills" does not exceed a certain proportion of the total amount of labor. In other words, when the labor-intensive sector expands, not all labor previously working in the importing sector can successfully function in the exporting sector. As an example, when the textile industry expands but the steel mills are shut down, not all former steel-workers can be productive textile workers. Formally, we model the frictions by the following inequality:

$$
L_{1 t} \leqslant \mu_{L} L
$$

Similarly, the budget constraint (3.4) now becomes

$$
\begin{aligned}
& P_{t}\left[C_{t}+\frac{\psi_{b}}{2}\left(B_{t+1}-\bar{B}\right)^{2}\right]+B_{t+1}+I_{t} \\
= & {\left[\mu_{L} w_{1 t}+\left(1-\mu_{L}\right) w_{2 t}\right] L+r_{t} K_{t}+\left(1+r^{*}\right) B_{t}+T R_{t} }
\end{aligned}
$$


and all the analysis in the basic model goes through except that now we replace $w_{t}$ by $w_{t}^{c}=\mu_{L} w_{1 t}+\left(1-\mu_{L}\right) w_{2 t}$. Labor market frictions impede the expansion of the exporting sector. Thus a given trade reform produces a smaller response in both the trade volume and the current account.

\section{$5.3 \quad$ Numerical Results}

For numerical simulations, we focus on the case of credit constraints, while assuming no labor market frictions. (The results with labor market frictions are qualitatively similar.) We choose the same structural parameters as in the benchmark case. For financial frictions, we set the credit constraint parameter in the initial steady state $\mu_{k}=0.42$ so that the initial net export share is about $10 \%$.

The case of a tariff reduction from $15 \%$ to $10 \%$ under financial frictions is presented in Columns 5 and 6 in Table 4 . The return to capital in the importing sector, $r_{2}$, decreases, but $r_{1}$ in the exporting sector increases. The labor-intensive sector expands while the capital intensive sector shrinks, and both exports and imports increase. While the qualitative result is the same as the case without financial frictions (Columns 2 and 3 in Table 4), the magnitude of the changes is (much) smaller. Because the (labor-intensive) export sector cannot expand as much as before, the wage rate now declines. The increase in the net foreign asset position, $B / G D P$, is now $8 \%$ of GDP when there is credit constraint, compared to an increase of $11 \%$ of GDP in the absence of credit constraints. That is, the credit constraint reduces capital outflow by $3 \%$ of GDP. However, when the tariff is cut to $5 \%$, this effect is more substantial. Table 4 shows that the change of net foreign asset position is $23 \%$ of GDP in the benchmark case, but it drops dramatically to only $14 \%$ in the credit-constrained economy. In short, credit constraint can substantially reduce the change in a country's foreign asset position for a given trade reform.

We present, in Figure 6, the transitional dynamics of the economy after a tariff cut from $15 \%$ to $10 \%$ in the case with credit constraints. Compared to Figure 2 (the transitional dynamics after an identical tariff cut but without credit constraint), the adjustments are smaller. The implications of credit constraints for the balance-of-payments variables are best seen in Figure 7. For ease of comparison with the case of no credit constraint, we use thick bold lines to represent the transitional dynamics when there is credit constraint, and 
thin lines to represent the case of no credit constraint. From the upper left graph, it is clear that credit constraints reduce the impact of a given tariff cut on trade volumes. Similarly, in the lower-left graph, we can see that credit constraints induce a smaller current account response to the same tariff cut than the case of no credit constraints. From the upper right graph, we can see that the smaller current account response comes from a combination of a smaller savings response and a smaller investment response. As shown in the lower right graph, the accumulation of foreign assets is also stunted by credit constraints.

\section{Concluding Discussion}

A wave of trade liberalizations take place in both developing and developed countries, including China's trade reforms during 2001-2006 following its WTO accession. At the same time, China's current account has risen to an unprecedented level. This surplus declined gradually after 2008. We suggest that the two developments are intimately related. By embedding a modified Heckscher-Ohlin structure and an endogenous discount factor into an intertemporal model of current account, we obtain two key results. First, trade liberalizations in a developing country (that reduce its capital intensity) would generally lead to a capital outflow, while trade liberalizations in a developed country (that increase its capital intensity) would result in a capital inflow. Thus, trade reforms can produce or contribute to global imbalances. Because such current account imbalances are generated by welfare-improving trade reforms, they do not call for a policy correction. Second, factor market frictions can reduce the current account response to trade reforms by reducing the extent of economic structural change.

This model offers an interesting interpretation of the Chinese experience with trade reforms and current account dynamics (both the rapid rise during 2002-2007 and the fall after 2007). In particular, there are two phases of trade policy changes that appear to be associated with different current account patterns. Before China's accession to the WTO at the end of 2001, while there had been trade reforms, financial sector frictions may have blunted the current account response. In comparison, the WTO accession represents a watershed event in two senses. First, not only the dismantling of tariff and non-tariff barriers on imports was accelerated but there was also a dramatic reduction in trading costs faced by firms in the exporting sector. In particular, Chinese firms that did not enjoy 
export rights before the WTO accession acquired an automatic right to exports as a result of the accession. (This reduction in trade costs is not captured by any measured reduction in tariff rates.) If one counts the number of trade reforms China has to undertake, it is more than two standard deviations greater than the median value for an accession country since 1990 (Tang and Wei, 2009). In that sense, China's trade reforms associated with its WTO accession may be called the mother of all trade reforms. Second, the accession protocol also obligates China to engage in a series of financial sector reforms over a fiveyear transition period after the accession. These reforms have also greatly facilitated the economic adjustment in the direction of expanding China's comparative advantage sectors and reducing its comparative disadvantage sectors.

The difference between the trade reforms in the 1990s and those associated with the WTO accession can be seen from the time series of the import-to-GDP ratio. The tariff cuts before 2001 had led to only a small change in the import/GDP ratio. In comparison, the WTO accession was followed by a large and sustained increase in the imports from $5 \%$ of GDP in 2001 to close to $30 \%$ of GDP by 2007. Interpreted in light of our model, the combination of trade reforms and factor market reforms brought out by the WTO accession has the effect of producing a large and positive current account response. Because both trade reforms and financial reforms were conducted over a multi-year phase, the current account response gains strength overtime in the first few years after the WTO accession before it peters out.

Our theory also sheds new light on the relative decline in China's current account surplus after 2007. A common explanation for the current account contraction is a temporary reaction to the contraction of global trade associated with the global financial crisis. The implication is that the Chinese current account surplus could return to its pre-2007 level once the world economy is out of recession. However, our model provides an additional explanation. In our model, the current account response to a trade policy shock is temporary (even though it can last for 20 quarters). Therefore, part of the decline of the current account surplus could result from the end of major trade reforms. The change in current account due to this factor is not likely to be reversed.

The end of the import quotas on textiles and garments by the United States and Europe in 2004 represents another important event that reduces trading costs. Since this was 
a reduction in trade barriers on a labor-intensive product in the United States, our theory would predict that the U.S. responds by running a current account deficit. More importantly, because textiles and garments are an important comparative advantage sector for China, the end of quotas in 2004 represented a big decline in the export costs for Chinese exporting firms. Therefore, this event also reinforces the rise of China's current account surplus in recent years. Because Europe is commonly said to have a less flexible labor market, our theory would predict a smaller current account response to the trade policy response, which appears to be consistent with the pattern in the data.

We do not wish to claim that trade reforms are the only factor that matters for the evolution of a country's current account. Rather, it is an important contributing factor that is thus far neglected in the discussion of current account imbalances. Such omission could incorrectly color one's understanding of the source of current account imbalances and appropriate policy responses. To put it simply, if a portion of the current account imbalances is caused by efficient trade reforms, we do not need to view it as a problem that needs a policy correction.

The basic general equilibrium logic linking trade reforms and capital flows is not unique to China. We will see many more trade policy changes in both developed and developing countries (not always in the direction of reducing trade barriers). We will also see many more changes in factor markets around the world that could either enhance or reduce their flexibility. This paper provides a way to think about the general equilibrium implications of trade reforms for international capital flows.

\section{References}

[1] Alessandria, George, Horag Choi, and Dan Lu, 2016, "Trade Integration and the Trade Balance in China", University of Rochester, Working Paper.

[2] Antras, Pol and Ricardo J. Caballero, 2009, "Trade and Capital Flows: A Financial Frictions Perspective," Journal of Political Economy, 117(4), pp. 701-744.

[3] Backus, David K., Patrick J. Kehoe, and Finn E. Kydland, 1992, "International Real Business Cycles," Journal of Political Economy, 100(4), pp. 745-775. 
[4] Backus, David K., Patrick J. Kehoe, and Finn E. Kydland, 1994, "Dynamics of the Trade Balance and the Terms of Trade: The J-Curve," American Economic Review, 84(1), pp. 84-103.

[5] Barattieri, Alessandro, 2014, "Comparative advantage, service trade, and global imbalances," Journal of International Economics, 2014, 92 (1), 1-13.

[6] Barattieri, Alessandro, 2018, "Asymmetric Trade Liberalizations and Current Account Dynamics," Manuscript, ESG-UQAM.

[7] Caballero, Ricardo J., Emmanuel Farhi, and Pierre-Olivier Gourinchas, 2008, "Financial Crash, Commodity Prices, and Global Imbalances," Brookings Papers on Economic Activity, 2008(2), 1-55.

[8] Cass, David, 1965. "Optimum Growth in an Aggregative Model of Capital Accumulation". Review of Economic Studies. 32 (3): 233-240.

[9] Choi, Horag, Nelson C. Mark, and Donggyu Sul, 2008, "Endogenous Discounting, the World Saving Glut and the U.S. Current Account," Journal of International Economics, 75(1), 30-53.

[10] Cunat, Alejandro and Marco Maffezzoli, 2004, "Heckscher-Ohlin Business Cycles," Review of Economic Dynamics, 7(3), 555-585

[11] Curtis, Chadwick and Nelson Mark, 2010, "Business Cycles, Consumption and RiskSharing: How Different is China?" in Yin-Wong Cheung, Vikas Kakkar, and Guonan Ma, (eds.), The Evolving Role of Asia in Global Finance.

[12] Daniel, Betty C, 1997, "Precautionary Saving and Persistent Current Account Imbalance," Journal of International Economics, 42(1):179-193.

[13] Devereux, Michael B., 1991. "Government Purchases and Real Interest Rates with Endogenous Time Preference," Economics Letters, Elsevier, vol. 35(2), pages 131-136, February.,

[14] Devereux, Michael and Khang Min Lee, 1999, "Endogenous Trade Policy and the Gains from International Financial Markets," Journal of Monetary Economics, 43, 35-59. 
[15] Epstein, Larry G., 1983, "Stationary Cardinal Utility and Optimal Growth under Uncertainty," Journal of Economic Theory, 31(1), 133-152.

[16] Eaton, Jonathan and Samuel Kortum, 2002, "Technology, Geography, and Trade?" Econometrica, 70 (5): 1741-779.

[17] Eaton, Jonathan, Samuel Kortum, Brent Neiman, and John Romalis, 2016, "Trade and the Global Recession," American Economic Review, 106(11), 3401-3438.

[18] Feng, Ling, Zhiyuan Li, and Deborah Swenson, 2014, "Trade Policy Uncertainty and Exports: Evidence from China' WTO Accession," CESifo Working Paper, 4780.

[19] Fernandez, Andres, Michael Klein, Alessandro Rebucci, Martin Schindler, and Martin Uribe, 2016, "Capital Control Measures: A New Dataset," IMF Economic Review 64, 548-574

[20] Handley, Kyle and Nuno Limao, 2017, "Policy Uncertainty, Trade, and Welfare: Theory and Evidence for China and the United States," American Economic Review, 107(9): 2731-2783.

[21] Hanson, Gordon, 2012, "The Rise of Middle Kingdoms: Emerging Economies in Global Trade," Journal of Economic Perspectives, 26(2), 41-64.

[22] Hsieh, Chang-Tai and Peter J. Klenow, 2009, "Misallocation and Manufacturing TFP in China and India," The Quarterly Journal of Economics, Volume 124, Issue 4, Pages 1403-1448.

[23] Jin, Keyu, 2012, "Industrial Structure and Financial Capital Flows," American Economic Review, 102(5): 2111-2146.

[24] Jin, Keyu and Nan Li, 2012, "International Transmission through Relative Prices," CEPR Discussion Paper 1090.

[25] Ju, Jiandong, Kang Shi and Shang-Jin Wei, 2014, "On Connections between Intratemporal and Intertemporal Trades," Journal of International Economics, 92(S2): 3651. 
[26] Ju, Jiandong and Shang-Jin Wei, 2007, "Current Account Adjustment: Some New Theory and Evidence," NBER Working Paper, w13388.

[27] Ju, Jiandong and Shang-Jin Wei, 2010, "Domestic Institutions and the Bypass Effect of Financial Globalization," American Economic Journal: Economic Policy, 2, 173-204.

[28] Ju, Jiandong, Yi Wu and Li Zeng, 2010, "The Impact of Trade Liberalization on the Trade Balance in Developing Countries," IMF Staff Papers, 57(2), 427-449.

[29] Kehoe, Patrick J., and Fabrizio Perri, 2002, "International Business Cycles with Endogenous Incomplete Markets," Econometrica, 70, 907-928.

[30] Khandelwal, Amit, Peter Schott, and Shang-Jin Wei, 2013, "Trade Liberalization and Embedded Institutional Reform: Evidence from Chinese Exporters," American Economic Review, 103(6): 2169-2195.

[31] Mendoza, Enrigue, 1991, "Real Business Cycles in a Small Open Economy," American Economic Review, 81, 797-818.

[32] Mendoza, Enrique, Vincenzo Quadrini, and Jose-Victor Rios-Rull. 2009, "Financial Integration, Financial Deepness, and Global Imbalances," Journal of Political Economy, $117(3), 371-410$.

[33] Minford, A.P.L. and Peel, David. 2002 "Advanced Macroeconomics: A Primer," Cheltenham : Edward Elgar, 2002.

[34] Mundell, Robert, 1957, "International Trade and Factor Mobility," American Economic Review, 47, 321-335.

[35] Neumeyer, Pablo A., and Fabrizio Perri, 2005, "Business Cycles in Emerging Economies: The Role of Interest Rates," Journal of Monetary Economics, 52(2): 345380.

[36] Koopmans, Tjalling C. , 1965, "On the concept of optimal economic growth," in (Study Week on the) Econometric Approach to Development Planning, chap. 4, pp. 225-87. North-Holland Publishing Co., Amsterdam. 
[37] Obstfeld, Maurice, 1981, "Macroeconomic Policy, Exchange-Rate Dynamics, and Optimal Asset Accumulation," Journal of Political Economy, 89(6), 1142-1161.

[38] Obstfeld, Maurice, 1982, "Aggregate Spending and the Terms of Trade: Is There a Laursen-Metzler Effect?" Quarterly Journal of Economics, 97, 251-270.

[39] Obstfeld, Maurice and Kenneth Rogoff, 1996, "Foundations of International Macroeconomics", The MIT Press.

[40] Obstfeld, Maurice and Kenneth Rogoff, 2000, "The Six Major Puzzles in International Macroeconomics: Is There a Common Cause?" In NBER Macroeconomics Annual 2000, Volume 15, Bernanke and Rogoff.

[41] Ostry, Jonathan D. and Andrew K. Rose, 1992, "An Empirical Evaluation of the Macroeconomic Effects of Tariffs," Journal of International Money and Finance, 11: 63-79.

[42] Pierce, Justin, and Peter Schott, 2016, "The Surprisingly Swift Decline of US Manufacturing Employment," American Economic Review, 106(7): 1632-62.

[43] Ramsey, Frank P., 1928, "A Mathematical Theory of Saving," Economic Journal. 38 (152): 543-559.

[44] Reyes-Heroles, Recardo, 2015, "The Role of Trade Costs in the Surge of Trade Imbalances", Federal Reserve Board, Working Paper.

[45] Reyes-Heroles, Recardo, Sharon Traiberman, and Eva Van Leemput, "Emerging Markets and the New Geography of Trade: The Effects of Rising Trade Barriers," IMF Economic Review, 2020, 68, 456-508.

[46] Romalis, John. 2004, "Factor Proportions and the Structure of Commodity trade", The American Economic Review, 94(1): 67-97.

[47] Romer, David, 2011, "Infinite-Horizon and Overlapping-Generations Models". Advanced Macroeconomics (Fourth ed.). New York: McGraw-Hill. pp. 49-77. 
[48] Schmitt-Grohe, Stephanie, 1998, "The International Transmission of Economic Fluctuations: Effects of US Business Cycles on the Canadian Economy," Journal of International Economics, 44: 257-287.

[49] Schmitt-Grohe, Stephanie and Martin Uribe, 2003, "Closing Small Open Economy Models," Journal of International Economics, 61:163-185.

[50] Stiglitz, Joseph E, 1970, "Factor Price Equalization in a Dynamic Economy," Journal of Political Economy, 78(3): 456-88.

[51] Song, Zheng, Kjetil Storesletten, and Fabrizio Zilibotti, 2011, "Growing like China," American Economic Review, 101: 202-241.

[52] Tang, Man-Keung, and Shang-Jin Wei, 2009, "The Value of Making Commitments Externally: Evidence from WTO Accessions," Journal of International Economics, 78(2): 216-229.

[53] Uribe, Martin, 1997, "Exchange Rate Based Inflation Stabilization: the Initial Effects of Credible Plans," Journal of Monetary Economics, 39: 197-221.

[54] Uzawa, Hirofumi., 1968, "Time Preference, the Consumption Function, and Optimal Asset Holdings," in J. N. Wolfe (eds.), Capital and Growth: Papers in Honor of Sir John Hicks, The University of Edinburgh Press, Edinburgh (1968): 485-504.

[55] Wei, Shang-Jin, and Xiaobo Zhang, 2011, "The Competitive Saving Motive: Evidence from Rising Sex Ratios and Savings Rates in China," Journal of Political Economy, 119 (3): 511-564. 


\section{Appendices}

\subsection{Equations for the Steady State}

Given the factor prices $(w, r)$ and the holding of foreign asset $B$, the output $Y$, consumption $C$, investment $I$, aggregate demand $D$, and sectoral outputs $X_{1}$ and $X_{2}$ can be determined by the following six equations.

$$
\begin{gathered}
\frac{C}{Y}=\frac{\bar{C}}{\bar{Y}}[\beta(1+r-\delta)]^{\frac{1}{\psi}} \\
D=C+\frac{I}{P}+\frac{\psi_{b}}{2} B^{2} \\
P Y=P_{1} X_{1}+P_{2} X_{2} \\
\alpha_{1} P_{1} X_{1}+\alpha_{2} P_{2} X_{2}=r \frac{I}{\delta} \\
\left(1-\alpha_{1}\right) P_{1} X_{1}+\left(1-\alpha_{2}\right) P_{2} X_{2}=w L \\
P_{1} X_{1}+P_{2} X_{2} /(1+\tau)+r^{*} B=\zeta P D
\end{gathered}
$$

where $\zeta=\omega+(1-\omega) /(1+\tau)$. Equation (7.6) is derived from the current account equation in the steady state, $P_{1}^{*}\left(X_{1}-D_{1}\right)+P_{2}^{*}\left(X_{2}-D_{2}\right)+r^{*} B=C A=0$.

\subsection{Equilibrium Selection in the Initial Steady State}

In the initial steady state, we assume an exogenous export share, $s x$, and an import share, $s m$, to select the equilibrium. Let

$$
\begin{aligned}
& s x=\frac{N X_{1}}{P_{1} X_{1}+P_{2} X_{2}}>0 \\
& s m=\frac{N X_{2}}{P_{1} X_{1}+P_{2} X_{2}}<0
\end{aligned}
$$


Since $B$ is initially zero, using expressions of sectoral output, we have

$$
P_{1} X_{1}+P_{2} X_{2}=\frac{\left(\alpha_{2}-\alpha_{1}\right)(1+\tau) \zeta P D-\tau w L}{\left(1-\alpha_{1}\right)-(1+\tau)\left(1-\alpha_{2}\right)}
$$

Using the expressions for $X_{1}$ and $D_{1}$, we have

$$
s x=\frac{w L-P D\left[\left(1-\alpha_{2}\right)(1+\tau) \zeta+\omega\left(\left(1-\alpha_{1}\right)-(1+\tau)\left(1-\alpha_{2}\right)\right)\right]}{\left(\alpha_{2}-\alpha_{1}\right)(1+\tau) \zeta P D-\tau w L}
$$

This implies that given the initial share of export $s x$, we can determine the initial ratio of wage income to final good expenditure as below

$$
\frac{w L}{P D}=\frac{s x\left(\alpha_{2}-\alpha_{1}\right)(1+\tau) \zeta+\left(1-\alpha_{2}\right)(1+\tau) \zeta+\omega\left(\left(1-\alpha_{1}\right)-(1+\tau)\left(1-\alpha_{2}\right)\right)}{1+s x \tau}
$$

Let $\kappa=\frac{w L}{P D}$. We can solve for the initial output $\bar{Y}$ as

$$
\bar{Y}=\frac{w L}{P} \frac{\left(\alpha_{2}-\alpha_{1}\right)(1+\tau) \zeta \kappa^{-1}-\tau}{\left(1-\alpha_{1}\right)-(1+\tau)\left(1-\alpha_{2}\right)}
$$

In the initial steady state, the consumption is given by $C=D-\frac{I}{P}$, and the investment is given by $I=\delta K=\frac{\delta}{r}\left(\alpha_{1} P_{1} X_{1}+\alpha_{2} P_{2} X_{2}\right)$. From the determination of sectoral output, we have

$$
I=\frac{\delta}{r} \frac{(1+\tau)\left(\alpha_{2}-\alpha_{1}\right) \zeta P D-(1+\tau)\left(\alpha_{2}-\alpha_{1}\right) r^{*} B-\left(\alpha_{2}(1+\tau)-\alpha_{1}\right) w L}{\left(1-\alpha_{1}\right)-\left(1-\alpha_{2}\right)(1+\tau)}
$$

For simplicity, we rewrite it as

$$
\frac{I}{P}=\phi D+\Phi
$$

where

$$
\begin{aligned}
\phi & =\frac{\delta}{r} \frac{(1+\tau)\left(\alpha_{2}-\alpha_{1}\right) \zeta}{\left(1-\alpha_{1}\right)-\left(1-\alpha_{2}\right)(1+\tau)}>0 \\
\Phi & =-\frac{\delta}{r P} \frac{(1+\tau)\left(\alpha_{2}-\alpha_{1}\right) r^{*} B+\left(\alpha_{2}(1+\tau)-\alpha_{1}\right) w L}{\left(1-\alpha_{1}\right)-\left(1-\alpha_{2}\right)(1+\tau)}
\end{aligned}
$$


Note that $\Phi$ is an investment component determined by the supply side. Therefore, substituting them into the aggregate demand equation, the initial consumption can be expressed as

$$
\bar{C}=D\left[(1-\phi)-\frac{\Phi}{D}\right]
$$

where

$$
\frac{\Phi}{D}=-\frac{\delta}{r} \frac{\alpha_{2}(1+\tau)-\alpha_{1}}{\left(1-\alpha_{1}\right)-\left(1-\alpha_{2}\right)(1+\tau)} \frac{w L}{P D}
$$

Finally, we obtain the initial consumption as below:

$$
\bar{C}=\frac{w L}{P}\left[\frac{1-\phi}{\kappa}+\frac{\delta}{r} \frac{\alpha_{2}(1+\tau)-\alpha_{1}}{\left(1-\alpha_{1}\right)-\left(1-\alpha_{2}\right)(1+\tau)}\right]
$$

\subsection{Steady-State Equilibrium with Credit Constraint}

$$
\begin{gathered}
B=\frac{1}{\psi_{b} P} \frac{r^{*}-r^{C}+\delta}{1+r^{C}-\delta} \\
\left(\frac{w}{A_{1}}\right)^{1-\alpha_{1}} r_{1}^{\alpha_{1}}=P_{1}^{*} \\
\left(\frac{w}{A_{2}}\right)^{1-\alpha_{2}} r_{2}^{\alpha_{2}}=(1+\tau) P_{2}^{*} \\
\frac{K_{1}}{K_{2}}=\frac{\mu_{k}}{1-\mu_{k}} \\
L_{1}+L_{2}=L \\
r_{1} K_{1}=\alpha_{1} P_{1} X_{1} \\
r_{2} K_{2}=\alpha_{2} P_{2} X_{2} \\
w L_{1}=\left(1-\alpha_{1}\right) P_{1} X_{1} \\
w L_{2}=\left(1-\alpha_{2}\right) P_{2} X_{2} \\
r C=\mu_{k} K_{1}+\left(1-\mu_{k}\right) K_{2}
\end{gathered}
$$




$$
\begin{gathered}
P_{1} D_{1}=\omega P D \\
P_{2} D_{2}=(1-\omega) P D \\
D=C+\frac{\delta\left(K_{1}+K_{2}\right)}{P}+\frac{\psi_{b}}{2} B^{2} \\
P_{1} X_{1}+P_{2} X_{2} /(1+\tau)+r^{*} B=\zeta P D \\
\frac{C}{Y}=\frac{\bar{C}}{\bar{Y}}\left[\beta\left(1+r^{C}-\delta\right)\right]^{\frac{1}{\psi}}
\end{gathered}
$$


Table 1: Episodes of Trade Reforms (1990-2010)

\begin{tabular}{|c|c|c|c|c|c|c|c|}
\hline \multirow[b]{2}{*}{ Country Name } & \multirow[b]{2}{*}{ Period } & \multicolumn{2}{|c|}{ Tariff Change } & \multirow[b]{2}{*}{ Imports Change } & \multicolumn{3}{|c|}{ Financial Deregualation } \\
\hline & & $\begin{array}{l}\text { Simple } \\
\text { Average }\end{array}$ & $\begin{array}{l}\text { Weighted } \\
\text { Average }\end{array}$ & & $\begin{array}{l}\text { fkrsu Capital } \\
\text { Control Index }\end{array}$ & $\begin{array}{c}\text { IMF } \\
\text { Openness Index }\end{array}$ & $\begin{array}{c}\text { Chinn-Ito } \\
\text { Openness Index }\end{array}$ \\
\hline Albania* & 2001-2002 & -3.21 & -2.93 & 8.01 & / & Unchanged & Unchanged \\
\hline Algeria* & $2001-2003$ & -3.44 & -3.19 & 3.8 & Close & / & Unchanged \\
\hline Bangladesh* & 2003-2005 & -4.21 & 0.86 & 3.01 & Unchanged & Unchanged & Unchanged \\
\hline Bangladesh & 2006-2007 & -0.72 & -8.62 & 3.51 & Close & Close & Unchanged \\
\hline Belize & 1999-2001 & -9.18 & -0.48 & 6.31 & / & Unchanged & Close \\
\hline Bhutan & 2005-2007 & -0.24 & -5.01 & 4.27 & / & Unchanged & Unchanged \\
\hline Brazil* & 1989-1993 & -30.01 & -18.9 & 3.63 & / & / & Unchanged \\
\hline Brazil* & 1998-2001 & -1.76 & -5.52 & 4.56 & Open & Open & Open \\
\hline Cambodia* & 2003-2005 & -2.14 & -5.54 & 4.35 & / & / & Open \\
\hline Canada* & 1995-1997 & -3.3 & -2.34 & 3.4 & Open & / & Unchanged \\
\hline China* & 1992-1997 & -24.57 & -16.35 & 4.86 & / & / & Open \\
\hline China* & 2001-2003 & -4.52 & -7.63 & 6.88 & Unchanged & Unchanged & Unchanged \\
\hline Georgia* & $2002-2004$ & -3.1 & -1.33 & 4.02 & Unchanged & Unchanged & Unchanged \\
\hline Guyana & 1999-2001 & -9.73 & -3.59 & 6.14 & / & Unchanged & Open \\
\hline India* & 2004-2008 & -16.86 & -16.55 & 4.93 & Unchanged & Unchanged & Unchanged \\
\hline Indonesia* & 1989-1990 & -3.48 & 0.36 & 3.55 & / & / & Unchanged \\
\hline Indonesia* & 1995-1996 & -2.99 & -3.16 & 15.57 & Open & / & Close \\
\hline Indonesia* & 1999-2001 & -4.3 & -1.74 & 3.03 & Close & / & Close \\
\hline Kenya* & 2004-2006 & -4.11 & -3.44 & 3.1 & Open & Open & Unchanged \\
\hline Kyrgyz Republic* & $2002-2003$ & -3.33 & -2.52 & 7.92 & Open & Unchanged & Unchanged \\
\hline Lebanon & 2000-2001 & -8.72 & -8.69 & 4.01 & Close & Close & Close \\
\hline Lesotho & 2006-2007 & 0.05 & -3.04 & 5.22 & / & / & Unchanged \\
\hline Malawi* & 1996-1998 & -6.67 & -4.37 & 6.23 & / & Open & Unchanged \\
\hline Mauritius* & 1995-1997 & -0.99 & -4.91 & 3.19 & Close & / & Open \\
\hline Mauritius* & 2005-2006 & -2.96 & -3.5 & 7.05 & Close & Unchanged & Unchanged \\
\hline Morocco* & 2006-2009 & -6.13 & -4.61 & 5.19 & Unchanged & Open & Unchanged \\
\hline Nigeria* & 2001-2002 & 3.9 & -3.02 & 8.15 & Unchanged & Unchanged & Open \\
\hline Pakistan & 2001-2003 & -3.01 & -3.43 & 3.85 & Open & Open & Unchanged \\
\hline Paraguay* & 2004-2006 & -1.91 & -5.21 & 5.6 & Close & Close & Unchanged \\
\hline Peru* & 2006-2008 & -4.11 & -4.04 & 7.23 & Close & Close & Unchanged \\
\hline Philippines & 1989-1990 & -8.68 & -7.66 & 3.02 & / & / & Unchanged \\
\hline Seychelles* & 2005-2006 & -3.64 & -0.45 & 4.13 & / & Unchanged & Unchanged \\
\hline St Lucia* & 2000-2001 & -9.76 & -4.25 & 4.16 & / & / & Unchanged \\
\hline Syrian Arab Republic & 2009-2010 & 0 & -4.03 & 4.61 & / & / & / \\
\hline Thailand* & 1993-1995 & -22.66 & -21.7 & 6.39 & / & / & Unchanged \\
\hline Thailand* & 2003-2005 & -3.46 & -4.15 & 6.94 & Close & Close & Unchanged \\
\hline Tunisia* & $2002-2008$ & -12.4 & -10.46 & 3.36 & Unchanged & Unchanged & Unchanged \\
\hline Zimbabwe & $1996-2003$ & -25.1 & -22.45 & 8.67 & / & Unchanged & Close \\
\hline
\end{tabular}

Note: *denotes the countries for which data on current account and capital intensity are both avaiable. For capital account openness, open (close) means the capital account becomes more (less) liberalized after the trade reform. 
Table 2: Changes in Current Account and Changes in Trade Policy, 1990-2010

\begin{tabular}{|c|c|c|c|c|c|c|c|}
\hline \multirow[b]{2}{*}{ VARIABLES } & \multicolumn{7}{|c|}{ Dependent variable $=\Delta(\mathrm{CA} / \mathrm{GDP})$} \\
\hline & (1) & $(2)$ & $(3)$ & (4) & $(5)$ & $(6)$ & (7) \\
\hline$\Delta$ K-Intensity & $\begin{array}{c}-61.69^{*} \\
(30.26)\end{array}$ & $\begin{array}{c}-139.8^{*} \\
(63.12)\end{array}$ & $\begin{array}{c}-61.38^{* *} \\
(29.39)\end{array}$ & $\begin{array}{c}-117.4^{* *} \\
(41.66)\end{array}$ & $\begin{array}{l}-64.62 \\
(41.08)\end{array}$ & $\begin{array}{c}-68.83^{* *} \\
(29.05)\end{array}$ & $\begin{array}{c}-68.53^{* *} \\
(29.16)\end{array}$ \\
\hline$\Delta \mathrm{RER}$ & & $\begin{array}{c}-0.0835^{*} \\
(0.0379)\end{array}$ & & & & & \\
\hline$\Delta$ CI Openness $\dagger$ & & & $\begin{array}{l}1.328 \\
(0.830)\end{array}$ & & & & \\
\hline$\Delta \mathrm{IMF}$ Openness $\dagger$ & & & & $\begin{array}{c}5.045 \\
(6.179)\end{array}$ & & & \\
\hline$\Delta$ Cap. Control & & & & & $\begin{array}{l}-6.822 \\
(5.783)\end{array}$ & & \\
\hline Initial RCA in Merchandise & & & & & & $\begin{array}{l}3.837^{*} \\
(1.968)\end{array}$ & \\
\hline Initial RCA in Services & & & & & & & $\begin{array}{c}-0.894^{*} \\
(0.473)\end{array}$ \\
\hline Constant & $\begin{array}{c}-0.817^{*} \\
(0.430)\end{array}$ & $\begin{array}{c}-1.932^{* *} \\
(0.772)\end{array}$ & $\begin{array}{c}-1.028^{* *} \\
(0.438)\end{array}$ & $\begin{array}{c}-1.179^{*} \\
(0.591)\end{array}$ & $\begin{array}{l}-0.598 \\
(0.532)\end{array}$ & $\begin{array}{c}-4.555^{* *} \\
(1.993)\end{array}$ & $\begin{array}{c}0.172 \\
(0.642)\end{array}$ \\
\hline Observations & 28 & 13 & 28 & 17 & 19 & 27 & 27 \\
\hline R-squared & 0.138 & 0.380 & 0.218 & 0.363 & 0.213 & 0.269 & 0.263 \\
\hline
\end{tabular}


Table 4: The Steady States Before and After a Tariff Reduction

\begin{tabular}{|c|c|c|c|c|c|c|}
\hline \multirow[t]{2}{*}{ Variable } & \multicolumn{3}{|c|}{ Benchmark (No Credit Constraint) } & \multicolumn{3}{|c|}{ With Credit Constraint } \\
\hline & tariff $=0.15$ & tariff $=0.1$ & tariff $=0.05$ & tariff $=0.15$ & tariff $=0.1$ & tariff $=0.05$ \\
\hline (1) & $(2)$ & $(3)$ & $(4)$ & $(5)$ & (6) & (7) \\
\hline$r^{c}$ & 0.035 & 0.033 & 0.030 & 0.035 & 0.033 & 0.032 \\
\hline$r_{1}$ & 0.035 & 0.033 & 0.030 & 0.035 & 0.034 & 0.034 \\
\hline$r_{2}$ & 0.035 & 0.033 & 0.030 & 0.035 & 0.033 & 0.031 \\
\hline$w_{1}$ & 1.659 & 1.720 & 1.787 & 1.658 & 1.686 & 1.695 \\
\hline$w_{2}$ & 1.659 & 1.720 & 1.787 & 1.658 & 1.686 & 1.695 \\
\hline$P_{1}$ & 3.262 & 3.262 & 3.262 & 3.262 & 3.262 & 3.262 \\
\hline$P_{2}$ & 0.348 & 0.334 & 0.320 & 0.348 & 0.334 & 0.320 \\
\hline$P$ & 1.066 & 1.044 & 1.022 & 1.066 & 1.044 & 1.022 \\
\hline$C$ & 2.069 & 2.100 & 2.124 & 2.068 & 2.082 & 2.081 \\
\hline$D$ & 3.055 & 3.211 & 3.363 & 3.053 & 3.147 & 3.199 \\
\hline$B$ & 0.345 & 0.713 & 1.086 & 0.342 & 0.602 & 0.803 \\
\hline$K$ & 42.043 & 46.379 & 50.602 & 41.989 & 44.480 & 45.710 \\
\hline$I$ & 1.051 & 1.159 & 1.265 & 1.050 & 1.112 & 1.143 \\
\hline$Y$ & 2.940 & 3.095 & 3.241 & 2.939 & 3.034 & 3.091 \\
\hline$K_{1}$ & 18.254 & 20.536 & 23.422 & 18.223 & 19.304 & 19.838 \\
\hline$K_{2}$ & 23.789 & 25.843 & 27.180 & 23.766 & 25.176 & 25.872 \\
\hline$L_{1}$ & 0.784 & 0.790 & 0.803 & 0.784 & 0.790 & 0.798 \\
\hline$L_{2}$ & 0.216 & 0.210 & 0.197 & 0.216 & 0.210 & 0.202 \\
\hline$X_{1}$ & 0.595 & 0.622 & 0.657 & 0.595 & 0.609 & 0.619 \\
\hline$X_{2}$ & 3.424 & 3.599 & 3.657 & 3.422 & 3.536 & 3.560 \\
\hline$D_{1}$ & 0.499 & 0.514 & 0.527 & 0.499 & 0.504 & 0.501 \\
\hline$D_{2}$ & 4.674 & 5.014 & 5.365 & 4.671 & 4.914 & 5.103 \\
\hline$N X_{1}$ & 0.313 & 0.352 & 0.423 & 0.313 & 0.343 & 0.384 \\
\hline$N X_{2}$ & -0.435 & -0.473 & -0.547 & -0.435 & -0.461 & -0.495 \\
\hline$C A / G D P$ & 0.000 & 0.000 & 0.000 & 0.000 & 0.000 & 0.000 \\
\hline$s x$ & 0.100 & 0.109 & 0.128 & 0.100 & 0.108 & 0.121 \\
\hline$s m$ & -0.139 & -0.146 & -0.165 & -0.139 & -0.145 & -0.157 \\
\hline$B / G D P$ & 0.110 & 0.220 & 0.328 & 0.109 & 0.190 & 0.254 \\
\hline$T V / G D P$ & 0.221 & 0.242 & 0.284 & 0.221 & 0.240 & 0.270 \\
\hline$C / G D P$ & 0.704 & 0.679 & 0.655 & 0.704 & 0.686 & 0.673 \\
\hline$I / G D P$ & 0.335 & 0.359 & 0.382 & 0.335 & 0.351 & 0.362 \\
\hline
\end{tabular}


Figure 1: Chinese Tariff Rates and Current Account during 1998-2010

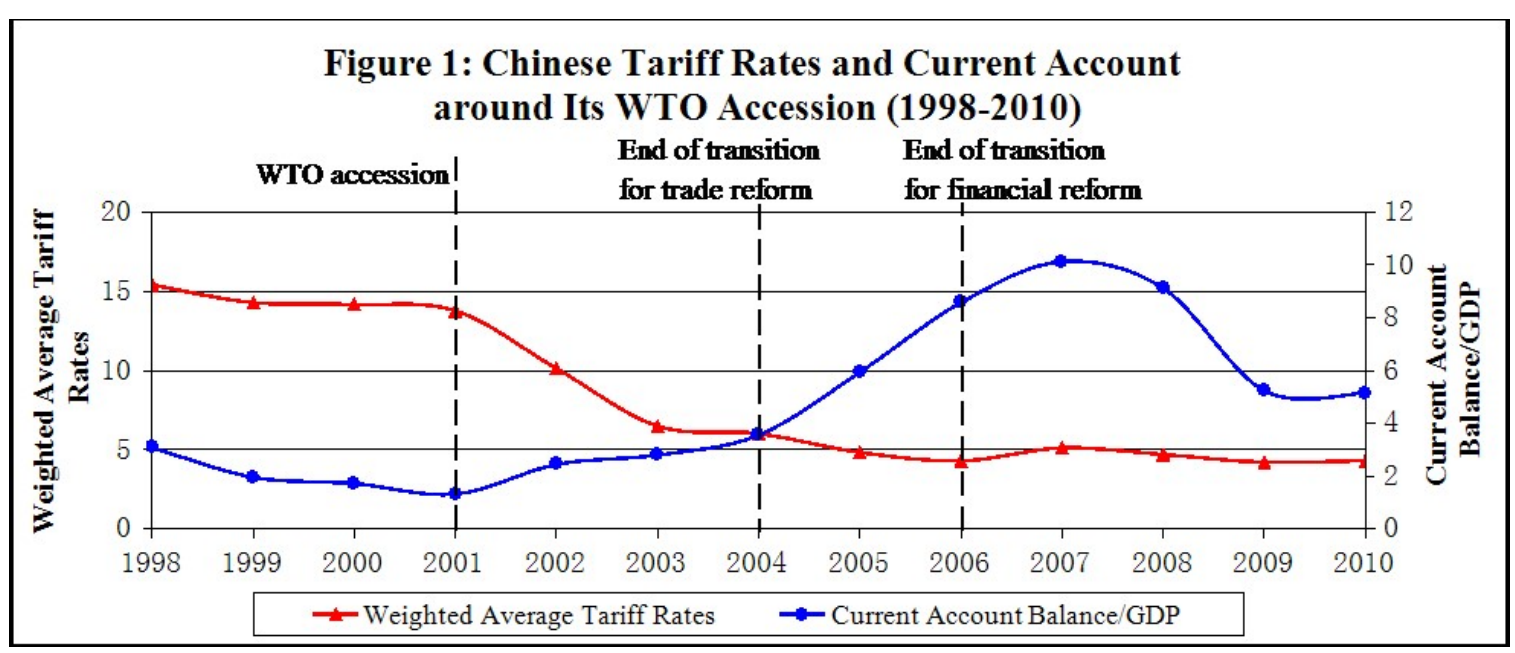


Figure 2: Transition Paths of the Economy after A Tariff Reduction by 5 Percentage Points (from $15 \%$ to $10 \%$ )
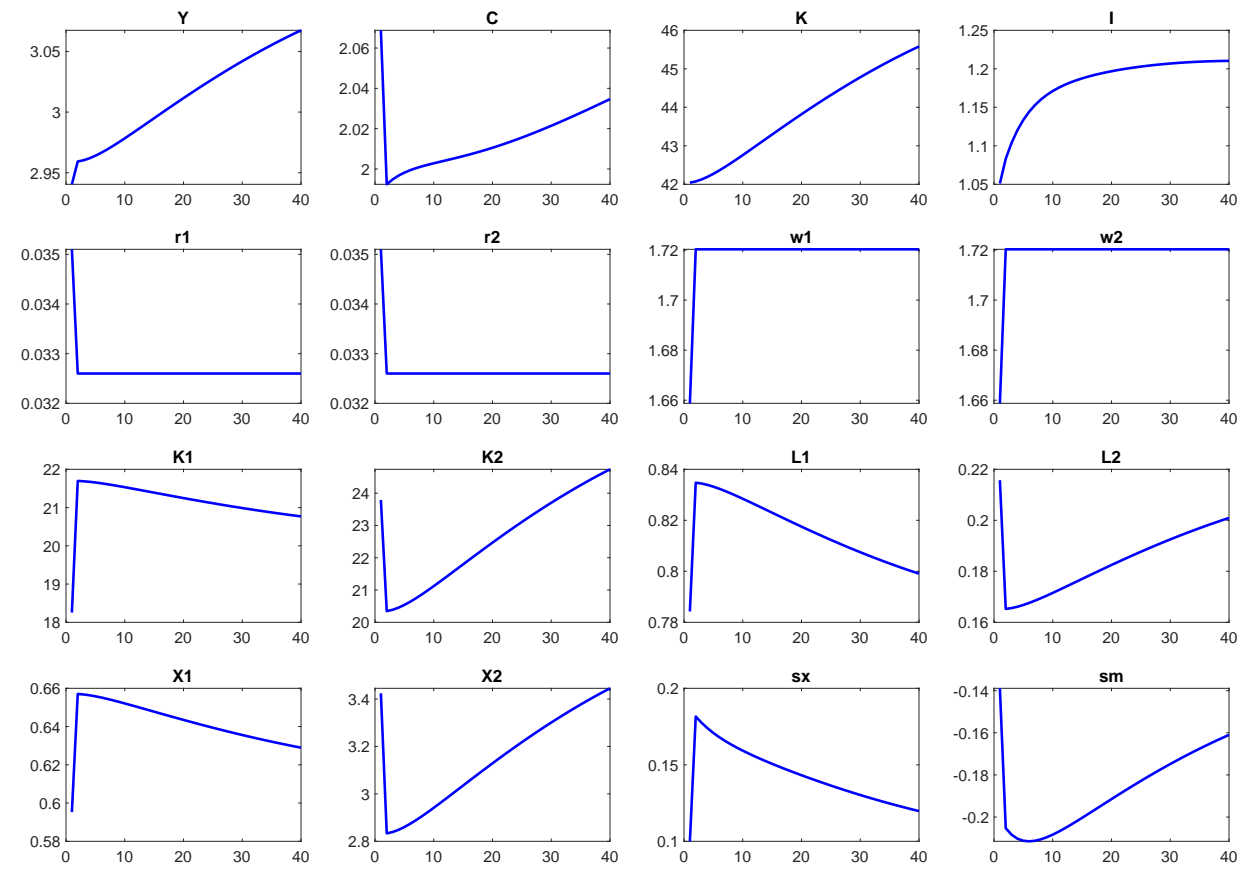
Figure 3: Dynamic Responses of the Trade Volume and the BOP Variables to a Tariff Reduction by 5 Percentage Points (from $15 \%$ to $10 \%$ )
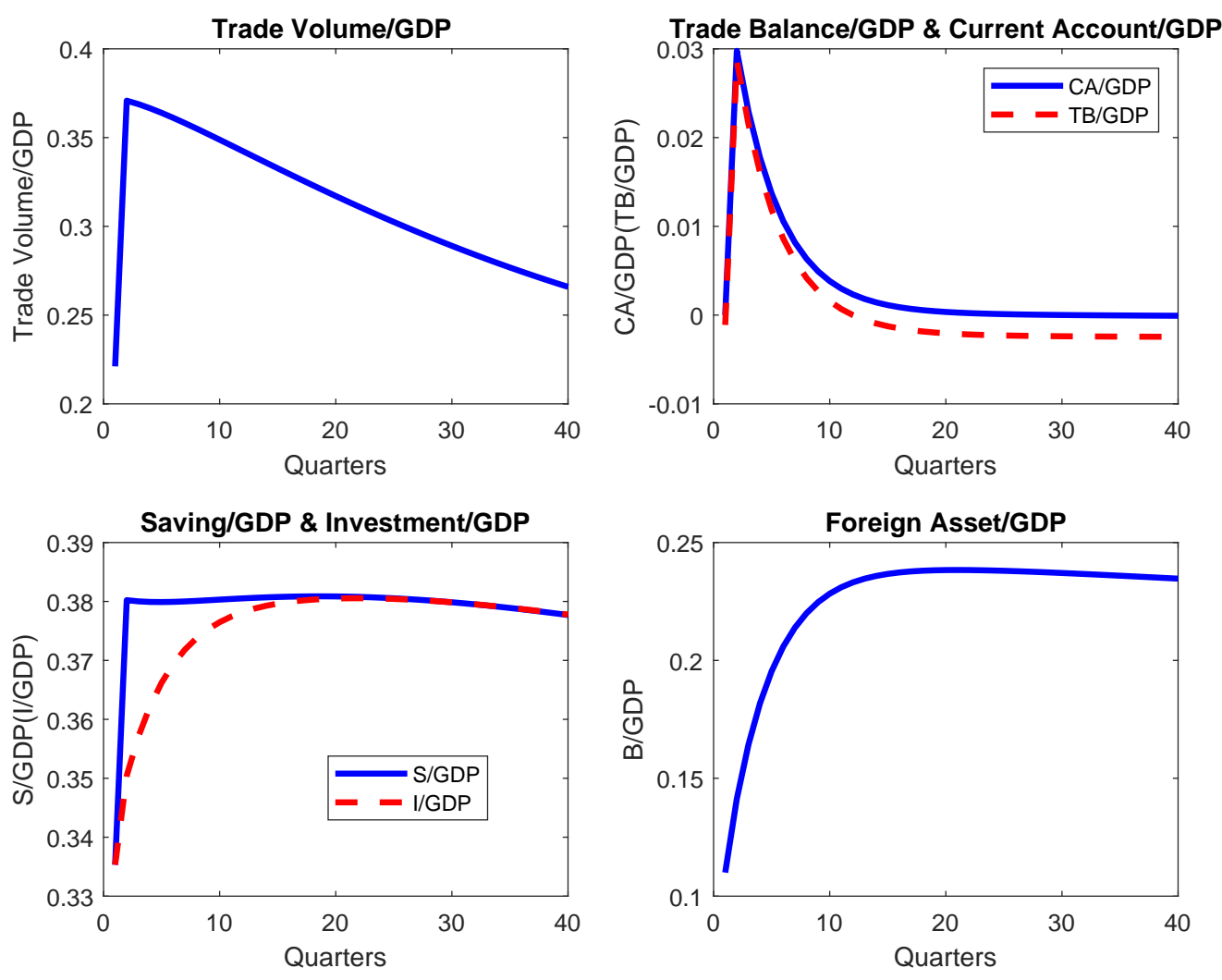
Figure 4: Dynamic Responses of the Trade Volume and the BOP Variables to a Tariff Cut by 5 Percentage Points and an Export Cost Reduction by 2 Percentage Points
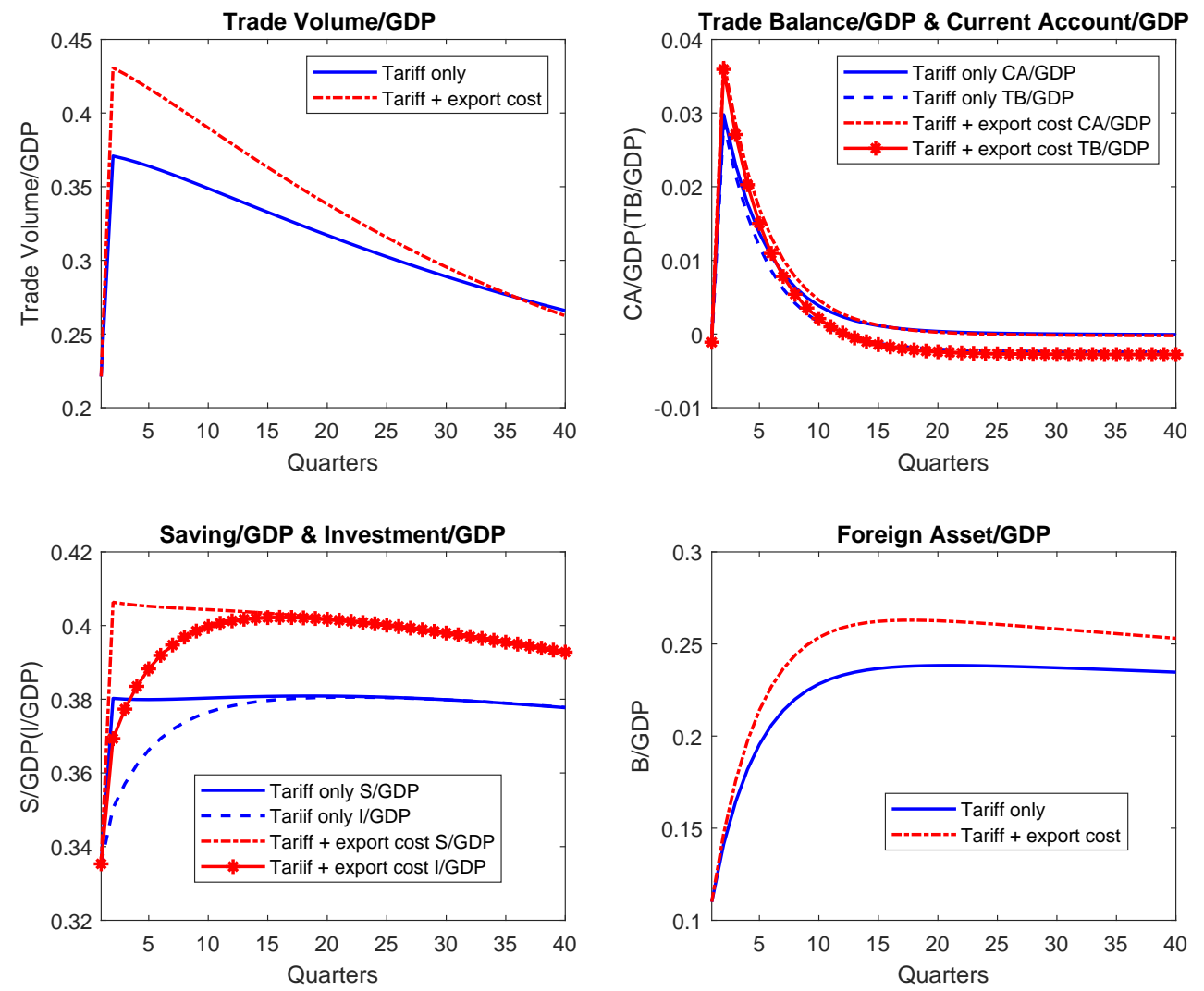
Figure 5: Transition Paths under Different Investment and Bond Adjustment Costs
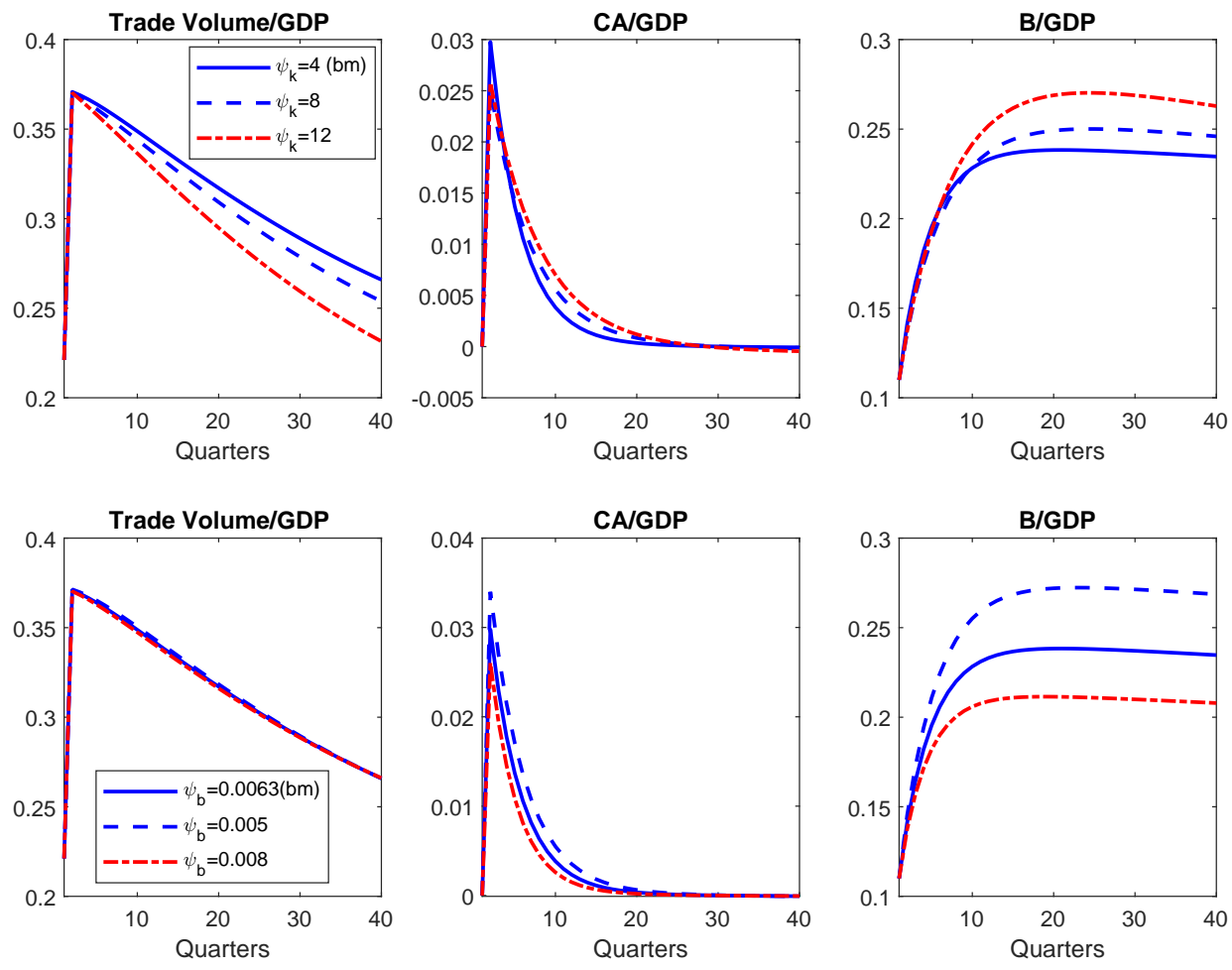
Figure 6: Transition Paths under Credit Constraints after a Tariff Cut by 5 Percentage Points (from $15 \%$ to $10 \%$ )
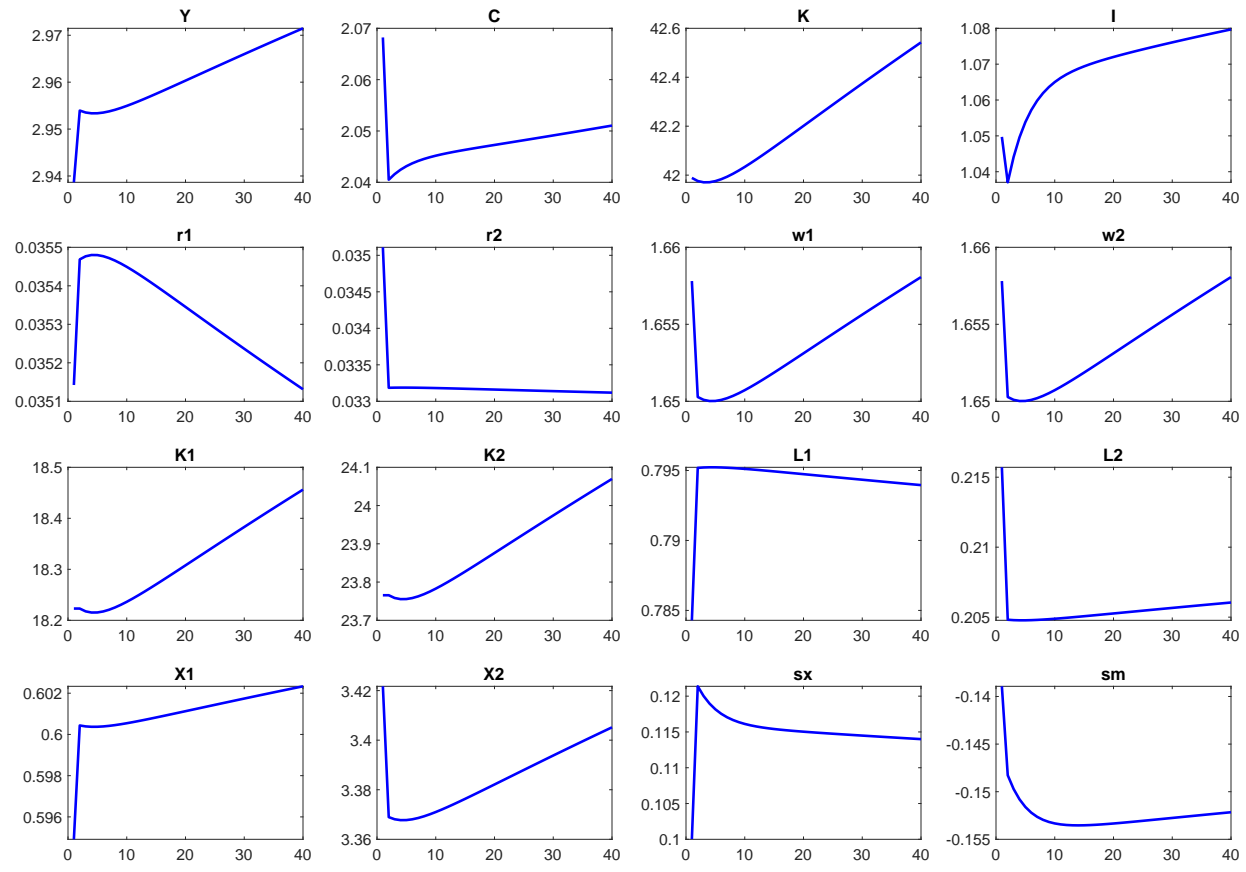
Figure 7: Responses of the BOP Variables with and without Credit Constraints to a Tariff Cut by 5 Percentage Points (from $15 \%$ to 10\%)
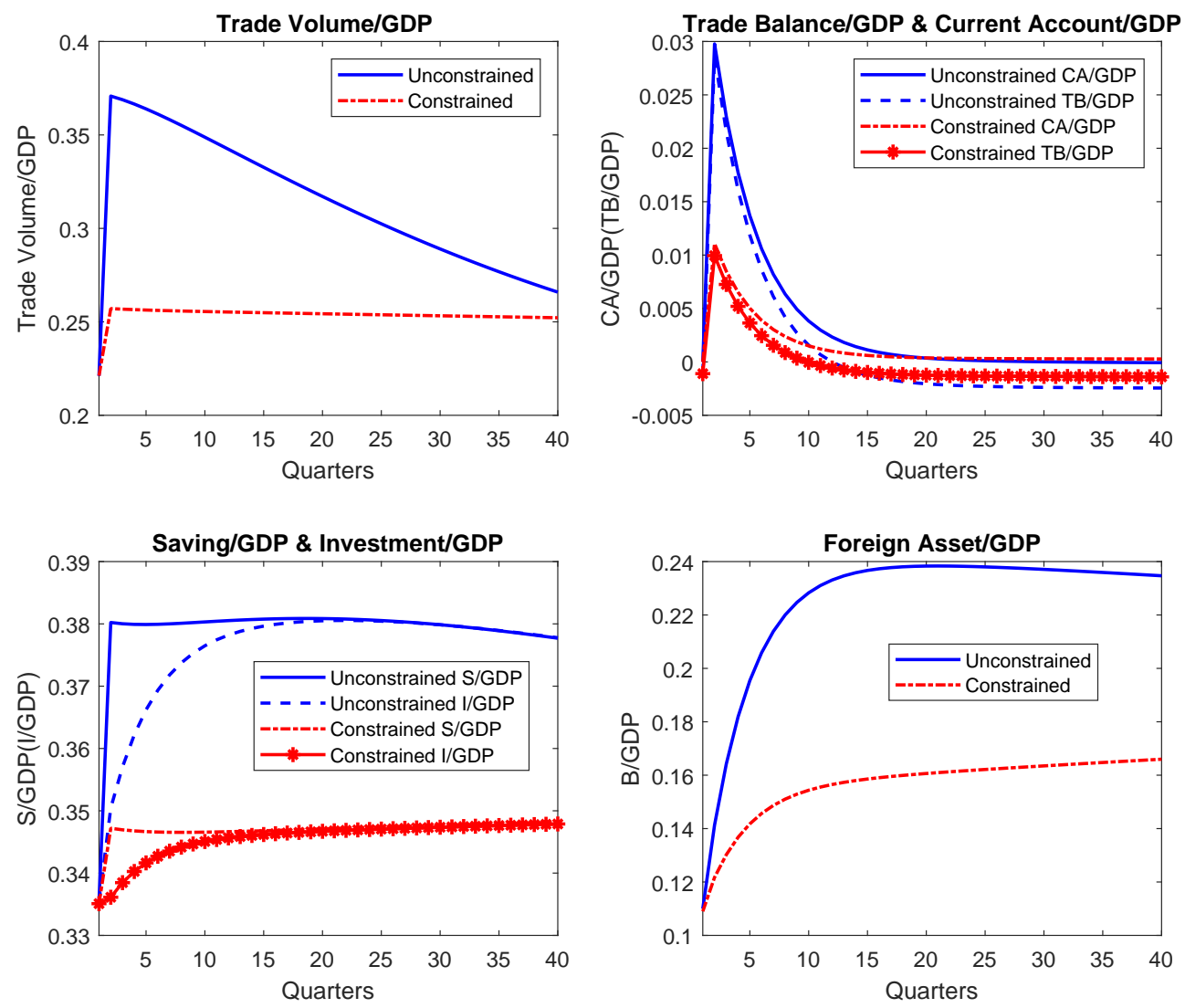